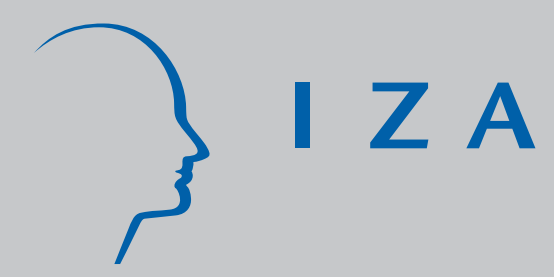

IZA DP No. 1663

Unemployment and Transitions in the Turkish Labor Market:

Evidence from Individual Level Data

H. Mehmet Tasci

Aysit Tansel

J uly 2005 


\title{
Unemployment and Transitions in the Turkish Labor Market: Evidence from Individual Level Data
}

\author{
H. Mehmet Tasci \\ Middle East Technical University \\ Aysit Tansel \\ Middle East Technical University \\ and IZA Bonn
}

Discussion Paper No. 1663

July 2005

IZA

P.O. Box 7240

53072 Bonn

Germany

Phone: +49-228-3894-0

Fax: +49-228-3894-180

Email: iza@iza.org

\begin{abstract}
Any opinions expressed here are those of the author(s) and not those of the institute. Research disseminated by IZA may include views on policy, but the institute itself takes no institutional policy positions.

The Institute for the Study of Labor (IZA) in Bonn is a local and virtual international research center and a place of communication between science, politics and business. IZA is an independent nonprofit company supported by Deutsche Post World Net. The center is associated with the University of Bonn and offers a stimulating research environment through its research networks, research support, and visitors and doctoral programs. IZA engages in (i) original and internationally competitive research in all fields of labor economics, (ii) development of policy concepts, and (iii) dissemination of research results and concepts to the interested public.
\end{abstract}

IZA Discussion Papers often represent preliminary work and are circulated to encourage discussion. Citation of such a paper should account for its provisional character. A revised version may be available directly from the author. 


\section{ABSTRACT}

\section{Unemployment and Transitions in the Turkish Labor Market: Evidence from Individual Level Data*}

This paper provides a systematic analysis of the determinants of transitions in the Turkish labor market by using the Household Labor Force Survey (HLFS) panel data of 2000 and 2001. We provide two types of evidence. First, we compute annual transition probabilities between the labor market states of employment, unemployment and out-of-the labor force under Markovian assumptions by gender and rural-urban residence and marital status. Transition probabilities are used to analyze the differences in unemployment rates of these groups. Second, we present estimates of gender-specific multinomial logit models to analyze the determinants of men's and women's transition probabilities across labor market states. We find that urban women have higher unemployment rates than urban men because they have lower probability of exiting unemployment for a job and higher probability of exiting employment for unemployment. Non-married men and women's unemployment rates are higher than married men and women's. This may be attributed to the higher probability of nonmarried men and women's to lose a job. Increases in education level are found to decrease the probability of losing a job. University graduates of two-year and over are more likely to find employment compared to non-graduates. Younger individuals are more likely to lose a job but older individuals are less likely to find a job from unemployment. In provinces with high unemployment the probability of obtaining a job is lower from unemployment. The findings indicate negative duration dependence for women, but not for men. Men improve their chances of obtaining a job if they use newspapers or worker agents.

JEL Classification: J23, J64, J16

Keywords: $\quad$ panel data, unemployment, transition probabilities, gender, Turkey

Corresponding author:

Aysit Tansel

Economics Department

Middle East Technical University

Ankara 06531

Turkey

Email: atansel@metu.edu.tr

\footnotetext{
* This paper is based on H. Mehmet Tasci's PhD thesis (see Tasci, 2005) prepared under the supervision of Aysit Tansel at the Department of Economics, METU. H. Mehmet Tasci would like to thank Hakan Ercan, Cem Somel, Yusuf Ziya Özcan, Abuzer Pinar and Murat Kirdar for helpful comments on his PhD thesis. Thanks are also due to Sefik Yildizeli and Ömer Demir past and current presidents of the State Institute of Statistics (SIS) of Turkey, Nurgül Ögüt former vice-president and Enver Tasti director of the Labor Force Statistics Department of SIS for their kind help in implementing this study. An earlier version of this paper was presented at the ERC/METU International Conference in Economics VII, September 2003 in Ankara. Thanks are also due to conference participants, particularly Insan Tunali, for helpful comments. Any errors are our own.
} 


\section{Introduction}

"The labor market is in continuous internal motion, with workers moving rapidly between jobs, unemployment and non-participation even during periods of stable economic activity" (Marston, 1976, p.169). This paper is concerned with the transitions between the labor market states. There are many studies on this topic for the developed countries, for example, Marston (1976) and Francesconi (1999) for the USA, Bellman et al. (1995) for Germany, Nielsen et al. (2000) for Norway, and Theeuwes et al. (1990) for Holland investigated the transitions. There are also several studies for the transition countries, for instance Huitfeldt (1996) and Lauerova and Terrel (2002) studied the transitions in the Czech Republic while Foley (1997) and Grogan (2000) studied the same in Russia. Studies for developing countries are scarce. Wolterman (2002) who studied the transitions in Brazil is the only study we encountered. Present paper is the first study of the transitions between labor market states in Turkey.

In February 2001, Turkey experienced the worst economic and financial crisis of the history of the republic. Gross Domestic Product declined by about 10 percent. Unemployment rate increased from 6.56 percent in 2000 to 8.32 percent 2001 . Economy recovered in 2002. Since then the economy grew at an average annual rate of 7.5 percent. The annual inflation rate declined from 68.5 percent in 2001 to 8.18 percent in 2005. The main feature of the post 2001 recovery period was "jobless growth". In spite of the high growth rates after the 2001 crisis, unemployment rate is in double digits. This emerges as a sign for concern. The numbers unemployed stood at 2.8 million people in the first quarter of 2005 with unemployment rate of 11.7 percent. The unemployment rate of the young was much higher with 22.2 percent for 
men and 21.2 percent for women.

In this paper we undertake a systematic study of the determinants of transitions in the Turkish labor market using the Household Labor Force Survey (HLFS) panel data of 2000 and 2001. Towards this end we provide two types of evidence. First, we compute annual transition probabilities between labor market states of employment, unemployment and out-of-the labor force by gender, ruralurban residence, marital status, age and educational groups. We then use the transition probabilities to analyze the differences in unemployment rates of these groups. We highlight the differences between urban men and urban women and between individuals with different marital status. We next present estimates of gender-specific multinomial logit models to analyze the determinants of men and women's transition probabilities across labor market states in Turkey. This analysis includes the factors which can explain the transition probabilities such as age, education, regions of residence, occupation, provincial unemployment rate etc. This process provides insights about factors affecting transition probabilities. The findings are important for designing policies to reduce the unemployment rate.

This paper proceeds as follows. The HLFS and sample data used in this paper are briefly described in Section 2. Section 3 presents the methodology. Section 4 presents transition probabilities between the labor market states under Markovian assumptions. Section 5 analyzes the sources of differentials in unemployment rates among some demographic groups by using Marston (1976)'s decomposition. Section 6 provides the estimation results of the multinomial-logit models for determinants of transitions out of employment, unemployment and not-in-the labor force. The final 
section provides the concluding remarks.

\section{The Data and Unemployment Characteristics}

The data used in this paper are taken from the Turkish Household Labor Force Survey (HLFS) which is nationally representative and covers rich information about the Turkish labor market. This survey was conducted biannually by the State Institute of Statistics of Turkey between 1988 and 1999. Since 2000, the survey has been implemented on a quarterly basis with a panel feature. The survey includes about 23,000 households in every quarter. It conveys information about all individuals in the household.

The panel feature of the HLFS makes it possible to measure the changes between successive quarters and years (SIS, 2001b:18). Approximately, half of the individuals surveyed in the first quarter of 2000 are re-interviewed in the first quarter of 2001 in which the sample is still representative of the country (SIS, 2001b:24). This property allows us to follow the individuals through time. For example, we can observe whether an unemployed individual finds a job, or an employed individual loses his/her job over time.

HLFS distinguishes between the labor market states of employed, unemployed, and out-of-the labor force. Following internationally accepted definitions are used in order to identify these labor market states. The employed covers all individuals aged 15 or over who during the reference period were economically active for at least one hour. They could be regular employee, casual 
employee, employer, self-employed or family worker. Individuals who did not work during the reference period for various reasons but have a job attachment are also included. The unemployed includes all individuals aged 15 or over who were not employed at any job even one hour, who have no job attachment during the reference period. They should have used also at least one of the job search channels for seeking work during the last three months and should be available to start work within 15 days. The remaining individuals aged 15 or over comprise the out-of-the labor force group (SIS, 2001a:XXIII-XXIV).

In this paper first two quarters of the 2000 and 2001 HLFS are used. The sample is restricted to individuals between the ages 15 and 65 . There are 19,653 matching individuals over the first quarters of 2000 and 2001 . The same number is 18,813 over the second quarters of 2000 and 2001.

Tables 1 and 2 report the main characteristics of the individuals in the three labor market states in the first and second quarters of 2000 and 2001, respectively. The labor force participation rate for all individuals was about 43 percent in the first quarter of 2000 and about 46 percent in the second quarter of 2001. This is very low compared to the labor force participation rates in the OECD countries (OECD database, 2004). Further women's labor force participation rate is in particular low at about 19-22 percent during the first and second quarters of 2000 and 2001 . We note that a low proportion of individuals who are non-graduate (illiterate plus literate without a diploma) is employed. Similarly, a rather low proportion of married females are employed. The unemployment rate for women is somewhat higher than for men. However, the unemployment rate for urban women is substantially higher 
than for urban men, 16 percent versus 9 percent in the first quarter of 2000. The unemployment rate for youth between 15-24 years is also very high, 17 percent for men and 21 percent for women in the first quarter of 2000. Further, we note that the unemployment rate of non-married men (17 percent) and women (19 percent) are much higher than that of the married men ( 6 percent) and women ( 6 percent).

The trends in annual urban versus rural unemployment rates, between 1988 and 2004, are provided in Figure 1. The rate of unemployment for urban men has been quite steady while for urban women it has been on a declining trend. Nevertheless, the recent economic and financial crisis negatively affected these tendencies (Tunali 2003:45). Especially, in the years between 2000 and 2002, the rate of unemployment increased from 7.77 percent to 13.07 percent for urban men and from 13.00 percent to 18.81 percent for urban women. The unemployment rates have been noticeably lower in rural areas. In the rural areas about 88 percent of female labor force and about 57 percent of the male labor force were employed in the agricultural sector (SIS, 2005). This finding supports the suggestion of Tunalı (2003:44) that "while women have traditionally been economically active in familyowned farms, young men have sought work outside agriculture to supplement farming income". Therefore, the rate of unemployment for rural women is generally lower than for rural men while the rate of unemployment of urban women is much higher than that of urban men.

Trends in unemployment rates by gender and marital status over time are shown in Figure 2. An increase in these rates after the 2001 crisis is obvious in this figure also. The figure shows that unemployment rates of non-married men and women are much higher than those for married men and women. Therefore, this 
study seeks to provide reasons for the differential in unemployment rates of urban men and women and of the non-married versus married men and women.

\section{Methodology}

\subsection{Transition Probabilities Methodology}

The movement of the individuals from one labor market state to another is regarded as a dynamic process which can be described by a Markov Process. Individuals in each period are observed in one of the three labor market states of employment, unemployment and out-of-the labor force. Corresponding to these three labor market states nine transition probabilities between states $\mathrm{i}$ and $\mathrm{j}$ can be observed. These are provided in the following matrix notation as:

$$
T=\left[\begin{array}{lll}
P_{е е} & P_{е и} & P_{е о} \\
P_{\text {ие }} & P_{\text {ии }} & P_{u о} \\
P_{о е} & P_{о и} & P_{о о}
\end{array}\right]
$$

The cells of the matrix, $\mathrm{T}$, show the transition probabilities between the labor market states. For example, $P_{u u}$ denotes the probability that an individual stays in unemployment between time $t$ and $t+1 ; P_{u e}$ refers to the probability of leaving unemployment for employment, etc. The gross probability of transition from state i to state $j$ is defined as the ratio of the number of persons in state $\mathrm{i}$ at time $t$ who are in state $j$ at time $t+1$, to the stock of persons in the original state $\mathrm{i}$ at time $t$ (Marston, 1976). 
Marston (1976:171) states that we do not need to know all of the transition probabilities between the labor market states to depict the system. Since the probability of keeping the initial position in any one of the labor market state is equal to one minus the probability that the individual exits from the initial position for the other states, we need only two of the each row. Thus, we have six independent transition probabilities. All of these probabilities can be transformed in various alternative techniques. For example, one can calculate the "probability of successful labor-force entry" as (Marston, 1976:172):

$$
P_{n s}=\frac{P_{o e}}{P_{o e}+P_{o u}}
$$

Following the equation developed by Marston (1976) one can write the rate of unemployment (UR) in terms of the transition probabilities. Thus, if the transitions into and out of employment are equal and the transitions into and out of unemployment are equal, i.e. if the labor market is in a "steady state". the rate of unemployment can be written in terms of the transition probabilities as:

$$
U R=\frac{P_{e u}+\left(1-P_{n s}\right) P_{e o}}{P_{e u}+\left(1-P_{n s}\right) P_{e o}+P_{u e}+P_{n s} P_{u o}}
$$

It should be noted that the rate of unemployment shown in the equation (3) will not be equal to the actual unemployment rate due to the possible biases in the gross flow data and the fact that the labor market may not be in steady state (DeBoer and Seeborg, 1989:407). Nevertheless, this formula may be very functional in examining the impacts of changes in the transition probabilities on the rate of unemployment. 
We observe from equation (3) that rises in the $P_{e u}, P_{e o}$, and $P_{o u}$ rise the rate of unemployment. However, increases in $P_{u e}, P_{u o}$, and $P_{o e}$ reduce the rate of unemployment. Lauerova and Terrel (2002:7) suggest that if we can identify the transition probabilities that are crucial for decreasing the rate of unemployment for a particular labor market group, then we can design the appropriate policies to decrease the unemployment rate.

\subsection{Multinomial Logit Model}

We estimate a gender-specific multinomial logit model of transition probabilities in order to assess the effects of personal characteristics, employment characteristics and local labor market conditions. The multinomial logit model is given by:

$$
\operatorname{Pr}\left(Y_{i t}=j \mid Y_{i t-1}=k\right)=\frac{\exp \left(\beta^{\prime}{ }_{j} Z_{i}\right)}{\sum_{k} \exp \left(\beta^{\prime}{ }_{k} Z_{i}\right)}, \quad j, k=1,2,3
$$

where subscript $i$ represents the individual and $Z_{i j k}$ are the characteristics of the $i$-th individual moving from state $k$ to state $j$. The covariates included in the $\mathrm{Z}$ vector such as age, education, marital status etc. are described in Table 3. Greene (1994:666) states that the coefficients of the multinomial-logit model are difficult to interpret. Therefore, we obtain the marginal effects. The marginal effect of a covariate, $\mathrm{z}_{i}$, on the transition probability to state $j, P_{j}$, is given by:

$$
\frac{d P_{j}}{d z_{i}}=P_{j}\left[\beta_{j}-\sum_{k} P_{k} \beta_{k}\right]
$$


where $\beta_{j}$ and $\beta_{k}$ are the relevant elements of the parameter vector $\beta$. Consequently, the size of a variable's effect depends on the choice of $P j$ (Foley (1997:24) and Lauerova and Terrel (2002:8)). In this paper, we provide the estimates of marginal effects and their standard errors evaluated at the sample means of the variables.

\section{Estimates of Transition Probabilities}

In this section we will examine the annual transition probabilities between the first quarters of 2000 and 2001 in Table 4 and between the second quarters of 2000 and 2001 in Table 5. These probabilities are presented by gender, rural-urban residence, marital status, age and education groups.

\subsection{Transitions from Employment}

Table 4 (5) shows that the probability that an individual stays employed $\left(\mathrm{P}_{\mathrm{ee}}\right)$ from the first (second) quarter of 2000 to the first (second) quarter of 2001 is 79.47 (80.46) percent. Both of these probabilities are not very high because of the crisis experienced during the first two quarters of 2001 and the ensuing recession. Further,

$\mathrm{P}_{\mathrm{ee}}$ is lower for women with 61.4 percent than for men with 86.15 percent. As a result women have higher risk of losing their jobs compared to men. Most of the women who lose their jobs become discouraged and go out-of-the labor force rather than go into unemployment. Similar results hold if we consider rural-urban residence differential for men and women. The probability of remaining employed $\left(\mathrm{P}_{\mathrm{ee}}\right)$ is 
higher for urban men and women than for rural men and women in the first quarter results and the opposite holds in the second quarter results.

The probability of remaining employed for a married individual is higher than for a non-married individual between both the first and the second quarters. Further, the gender differential in $\mathrm{P}_{\mathrm{ee}}$ is higher for married than for non-married individuals. This gender gap for married individuals is 27.98 (18.00) percent between the first (second) quarter transitions while for non-married individuals it is 8.25 (9.9) percent between the first (second) quarter transitions. Hence, married men have lower probability of losing their jobs compared to married women. This makes sense in the Turkish context since married men as traditional breadwinners, show greater job attachment than married women.

The youngest age group 15-19 has higher probability of losing their jobs than the older age groups. We further observe that the probability of losing a job decreases with an increase in the education level. For men the probability of losing a job is less than ten percent for high school graduates and over in the first and second quarter transitions while for women this probability is less than ten percent only for university level education.

\subsection{Transitions from Unemployment}

The probability that an individual finds a job from unemployment $\left(\mathrm{P}_{\mathrm{ue}}\right)$ between the first quarters of 2000 and 2001 is 45.66 percent, which decreases to 42.66 percent between the second quarters of 2000 and 2001. This decrease must be 
attributed to the economic crisis experienced during the first two quarters of 2001 and the ensuing recession. The probability of remaining unemployed $\left(\mathrm{P}_{\mathrm{uu}}\right)$ is higher for women than for men in the both quarter transitions. The increase in the probability of going from unemployment to out-of-the labor force $\left(\mathrm{P}_{\mathrm{uo}}\right)$ from first to the second quarter transitions is striking. This probability increases from 4.45 percent to 26.81 percent for men and from 6.40 percent to 55.29 percent for women from the first to the second quarter transitions. The increase is much larger for women than for men. Similar patterns are observed for rural-urban and married-non-married groups. The increases in the probability of going from unemployment to out-of-the labor force are much larger for urban women than for urban men and for married women than for married men. The discouraged worker effect implies an increase in the probability of going from unemployment to out-of-the labor force during recessions (Seeborg and DeBoer, 1989). This increase was obvious during the second quarter transitions of the recession period. The discouraged worker effect is mostly observed for women rather than for men.

The probability of finding a job from unemployment is lowest for age groups 55 plus and age 15-19. The probability of going from unemployment to out-of-the labor force is highest for the same age groups. The probability of finding a job from unemployment shows an increase with the level of education except for the high school and vocational high school graduates in the first quarter transitions. In the second quarter transitions this probability increases with the level of education except for the vocational high school graduates. Further, the probability of going from unemployment to out-of-the labor force is larger for all education levels in the 
second quarter transitions than in the first quarter transitions. For instance, for the non-graduates this probability increases from 8.33 percent to 53.85 percent.

\subsection{Transitions from Out-of-the Labor Force}

The probability that an individual remains out-of-the labor force is about 86 percent for the first and second quarter transitions. The probability from out-of-the labor force to unemployment increases for women while it decreases for men from the first quarter to the second quarter transition. Similarly, this probability increases for married women while it decreases for married men from the first quarter to the second quarter transition. These observations imply that as economic conditions worsen from the first quarter to the next, male workers become unemployed and women reduce their reservation wage and enter the labor market as added-workers.

Men are more likely to find a job from out-of-the labor force than women: 22.89 percent versus 6.69 percent in the first quarter transition. Further, married men are least likely to remain out-of-the labor force (smallest $\mathrm{P}_{\mathrm{oo}}$ ) and most likely to find a job (highest $\mathrm{P}_{\mathrm{oe}}$ ) in both the first and second quarter transitions. The examination of transitions by age group indicates that the probability of going from out-of-the labor force to unemployment decreases smoothly with age. The 55-plus age group has the lowest probability of leaving for a job and the highest probability of remaining in out-of-the labor force in both quarter transitions. Analysis of the transitions by education level indicates that the probability of going from out-of-the labor force to unemployment increases with the level of education except for the two- and fouryear university level in the first quarter transition and except for the vocational high 
school level in the second quarter transition. Four-year university and over group has the highest probability of leaving for a job in both quarter transitions and lowest probability of remaining in out-of-the labor force in the second quarter transition.

In the next section we examine the transition probabilities by using the Marston's decomposition in equation (3).

\section{Sources of Unemployment Rate Differentials by Gender and Residence}

In order to understand the differentials in unemployment rates we should examine the differentials in all transition probabilities besides transitions in and out of unemployment. It is clear from the equation (3) that the unemployment rate is negatively correlated with the probabilities of $\mathrm{P}_{\mathrm{ue}}, \mathrm{P}_{\mathrm{uo}}$, and $\mathrm{P}_{\mathrm{oe}}$. Thus, the increases in these three transition probabilities will decrease the rate of unemployment. On the other hand, the probabilities of $\mathrm{P}_{\mathrm{eu}}, \mathrm{P}_{\mathrm{eo}}$ and $\mathrm{P}_{\mathrm{ou}}$ are positively related with the rate of unemployment and the increases in these probabilities will increase the rate of unemployment.

Let us first look at the sources of unemployment rate differentials between urban men and urban women. We know that larger values of the probabilities of $\mathrm{P}_{\mathrm{ue}}$, $\mathrm{P}_{\mathrm{uo}}$, and $\mathrm{P}_{\mathrm{oe}}$ for urban men compared to urban women increase the unemployment rate differential between urban men and urban women, since these transition probabilities decrease the rate of unemployment for urban men more than that for urban women. Therefore, as shown in Tables 6 and 7, urban women's larger unemployment rate is being forced by differences in the two probabilities. These are the probability of a move from unemployment and out-of-the-labor-force to 
employment $\left(\mathrm{P}_{\mathrm{ue}}\right.$ and $\left.\mathrm{P}_{\mathrm{oe}}\right)$. These probabilities are 34.10 (31.25) and 15.26 (13.19) percentage points larger for urban men than for urban women in the first (second) quarters. The difference in the $\mathrm{P}_{\text {uо }}$ is in favour of urban women (i.e. decreasing the rate of unemployment for urban women more than that for urban men). These are 1.82 (25.78) percentages in the first (second) quarter transitions. But this cannot compensate the other differences in probabilities of $\mathrm{P}_{\mathrm{ue}}$ and $\mathrm{P}_{\mathrm{oe}}$. Lauerova and Terrel (2002:12) reach the same conclusion for the Czech Republic in explaining the gender differential in unemployment rate. Let us now look at the other remaining three probabilities: $\mathrm{P}_{\mathrm{eu}}, \mathrm{P}_{\mathrm{eo}}$ and $\mathrm{P}_{\mathrm{ou}}$. We know that if one of these transition probabilities is lower for urban men than for urban women, it decreases rate of unemployment for urban men compared with that of for urban women. Thus, it increases the difference among them. However, as can be observed from the Tables 6 and 7, $\mathrm{P}_{\mathrm{eo}}$ and $\mathrm{P}_{\mathrm{ou}}$ are higher for urban women than urban men. These two probabilities contribute to increase the gender differential in urban unemployment rates, and the largest contribution comes from $\mathrm{P}_{\mathrm{eo}}$. Thus, urban women are more likely to leave the labor force from employment than urban men, i.e. become discouraged. Also, the difference in $\mathrm{P}_{\mathrm{eu}}$ is in favor of urban women, but this cannot compensate the other differences in $\mathrm{P}_{\mathrm{eo}}$ and $\mathrm{P}_{\text {ou }}$.

We now look at the unemployment rate differentials between non-married and married individuals. This gap is positive in the two transition periods. All the transition probabilities that determine the rate of unemployment are against the nonmarried individuals, except $\mathrm{P}_{\text {ио }}$ in the first quarter transition. The probability of losing a job and going to unemployment $\left(\mathrm{P}_{\mathrm{eu}}\right)$ is more than two times higher for nonmarried individuals than for the married in the first quarter transition. The difference 
between non-married women and men is also positive. The two main sources that explain non-married women's higher unemployment rate with respect to non-married men are the transition probability from unemployment to employment and from employment to not-in-the labor force. The difference in the first probability is -28.47 , that is, negatively related to the unemployment rate, and the second probability is 10.48, which is positively related to the unemployment rate in the first quarter transition. Therefore these probabilities increase the unemployment rate differential between non-married women and non-married men. As shown in the Table 8, the most pronounced difference in unemployment rates is seen between non-married women and married women. There are two sources of this difference; these are $\mathrm{P}_{\mathrm{ns}}$ and $\mathrm{P}_{\mathrm{eo}}$.

When we control for education, we observe that the unemployment rate differential between non-graduates and other education levels are negative for the individuals with less than university degree in both transition periods. It is observed from the Tables 8 and 9 that two main sources of this negative difference are the differential between $\mathrm{P}_{\mathrm{ns}}$ and $\mathrm{P}_{\mathrm{uo}}$. In the Tables 8 and 9 we provided the partial differences in unemployment rates for prime aged and education groups for men and women. These tables indicate that the difference between women and men is generally positive and the gender gap reaches its maximum level for the middle school graduates in the first quarter and for the high school graduates in the second quarter transition. 


\section{Multinomial-Logit Estimation Results}

In this section, we pool the two quarters (quarter transition data) of the HLFS and estimate each model at the means of the explanatory variables. Consequently we have 37,984 individuals in the multinomial-logit estimation. In the Appendix Table 1 we provide the means and the standard deviations of the variables used in the analysis by labor market state of origin; employment, unemployment and out-of-the labor force. In the following sections we discuss the estimation results ${ }^{3}$ of the models for each type of the transition separately.

\subsection{The Determinants of Transitions from Employment}

In this section we examine the determinants of transitions from employment to unemployment and to out-of-the labor force. The results are displayed in Table 10 separately for men and women ${ }^{4}$. We discuss the variables, in the order they appear in the table. For men marginal effects of living in urban areas on the transition from employment to unemployment are insignificant but become positive and significant when occupation dummies are excluded. The same marginal effects for women are positive and statistically significant. For both men and women the marginal effects of living in urban areas on the transition from employment to out-of-the labor force are positive and statistically significant. These results imply that individuals who live in the urban areas are more likely to lose their jobs compared to those who live in rural areas. We now examine the results for marital status. For men and women both, the marginal effects of being married on the transition from employment to

\footnotetext{
${ }^{3}$ In the tables from 10 to 12 , we provide the marginal effects and their standard errors calculated at means of the variables. These marginal effects are calculated by using "mfx" command of Stata.

${ }^{4}$ Estimation results for the whole sample are given in Taşçı (2005).
} 
unemployment are negative and statistically significant implying that because of family responsibilities, the married men and women are less likely to be unemployed. For men, the marginal effects of being married on the transition from employment to out-of-the labor force are negative and statistically significant while for women they are insignificant. The results imply that married men are less likely to go out-of-the labor force.

With regards to regions of residence, we observe that for men and women both there are no significant regional variations in the transitions from employment to unemployment. There are some significant regional differences in the transition from employment to out-of-the labor force. Men who live in the Black Sea region are more likely to go from employment to out-of-the labor force. Women who live in the Marmara, East Anatolia and the South East Anatolia regions are more likely to go out-of-the labor force if they lose their job. Considering the different levels of education, we observe that for men, the marginal effects of being two and four year university graduate on the transition from employment to unemployment are negative and statistically significant. While for women the marginal effects for different levels of education are not statistically significant. These results imply that university graduate men have lower risk of becoming unemployed compared to the base category of illiterates and non-graduates. For both men and women the marginal effects of different levels of education for the transition from employment to out-ofthe labor force are negative and mostly significant. These results imply that men who are graduates of primary school, vocational high school, two- and four-year universities and over are less likely to go out-of-the labor force when they lose their jobs. Similarly women, who are graduates of high school and over are also less likely 
to go out-of-the labor force when they lose their jobs. Thus, for both men and women, the probability of leaving a job for out-of-the labor force decreases with an increase in the education level.

Considering the different age categories, we observe that for men, the marginal effects on transition from employment to unemployment are mostly insignificant. The statistically significant marginal effects for age 20-24 and age 2534 are positive and imply that men in these age groups have higher risk of becoming unemployed compared to the base category of age 15-19. The statistically significant marginal effect for age 55 plus is negative when occupation dummies are excluded implying that older men have lower risk of becoming unemployed compared to the base category of age 15-19. Similar results and implications hold for women also. For both men and women the marginal effects of different age categories on transition from employment to out-of-the labor force are mostly significant and negative except for men age 55 plus which is positive. Thus, the probability of going from employment to out-of-the labor force declines with the increase in age except for men in their late careers. Examining the marginal effects of the local unemployment rate on the transition from employment to unemployment we observe that for men, they are positive and statistically significant while for women they are statistically insignificant. These results imply that men who live in high unemployment provinces are more likely to become unemployed. For both men and women the marginal effects of local unemployment rate on the transition from employment to out-of-the labor force are positive and statistically significant implying that men and women who live in high unemployment provinces are more likely to go out-of-the labor force when they lose their job. 
With regards to the effects of different occupation groups, we observe that for both men and women, the marginal effects on the transition from employment to unemployment are not statistically significant except for men for occupation 6 which is agricultural workers. The results imply that men agricultural workers are less likely to go from employment to unemployment compared to the base category of professional and related workers. For all of the other occupational categories this likelihood does not differ from that of the base category. For men, the marginal effects of the transition from employment to out-of-the labor force are all statistically insignificant implying that the likelihood of going out-of-the labor force does not differ for each of the occupational categories from that of the base category of professional and related workers. For women, the same marginal effects are all negative and statistically significant except for occupation 2 (administrative and managerial workers) and occupation 8 (workers not classified by occupation). The results imply that women in most of the occupational categories (occupation 3occupation 7) are less likely to go from employment to out-of-the labor force compared to the base category of professional and related workers. Next, we examine the results for the employment status. For men, all of the marginal effects on the transition from employment to unemployment are statistically significant. The results imply that casual employees (status 2) are more likely to become unemployed compared to regular employees, while the other employment statuses are less likely to become unemployed compared to regular employees. For women, the same marginal effects are all statistically insignificant except for unpaid family workers (status 6) who are less likely to become unemployed compared to regular workers. For both men and women all of the marginal effects of the transition from 
employment to out-of-the labor force are statistically significant. The results imply that men casual employees and men unpaid family workers are more likely to go outof-the labor force compared to regular employees while other employment statuses are less likely to go out-of-the labor force. For women, all of the employment statuses (status 2 - status 6) are more likely to go out-of-the labor force if they lose their job compared to the base category of regular employees.

Finally, we include a public sector dummy in order to capture the effect of establishment ownership. For men and women both the marginal effects on the transition from employment to unemployment are negative and statistically significant implying that workers in the public sector are less likely to become unemployed compared to private sector workers. For men the marginal effects on the transitions from employment to out-of-the labor force are negative and statistically significant implying that public sector workers are less likely to go out-of-the labor force while the same marginal effects for women are statistically insignificant.

\subsection{The Determinants of Transitions from Unemployment}

In this section we discuss the determinants of transitions from unemployment to employment and to out-of-the labor force. The estimation results are reported in Table 11 separately for men and women. In addition to the explanatory variables used in the previous section we included the duration of unemployment at first interview in order to capture the heterogeneity among the unemployed (Foley, 1997 and Huitfeldt, 1996). Further, it is highly likely that the probability of receiving an offer depends on an individual's job search strategy (Devine and Kiefer, 1991 and Hutifeldt, 1996). In order to capture this effect we also include a group of dummy 
variables for the job-search methods used by unemployed individuals.

We observe in Table 11 that for men, the marginal effects of living in urban areas on the transition from unemployment to employment are insignificant while for women they are positive and statistically significant. These results imply that women who live in urban areas are more likely to find a job from unemployment. For men the marginal effects of living in urban areas on the transition from unemployment to out-of-the labor force are insignificant while for women they are negative and statistically significant. These results imply that women who live in urban areas are less likely to move out-of-the labor force from unemployment compared to those who live in rural areas. With regards to marital status we observe that for men the marginal effect of being married is positive and significant when the occupation dummies are excluded implying that marriage increases the probability of finding a job from unemployment possibly due to family responsibilities. The same marginal effects are statistically insignificant for women. For men, the marginal effects of being married on transition from unemployment to out-of-the labor force are statistically insignificant while for women positive and significant at the 10 percent level. This result implies that married women are more likely to exit from unemployment to out-of-the labor force.

When we consider the effects of living in different regions we observe that on the transition from unemployment to employment all of the marginal effects are statistically insignificant except South-East Anatolia for men and East Anatolia for women. Thus, men who live in South East Anatolia are more likely to find a job and women who live in East Anatolia are less likely to find a job from unemployment 
compared to those who live in Central Anatolia. On the transition from unemployment to out-of-the labor force all of the marginal effects are statistically insignificant except East Anatolia for women. Thus, women who live in East Anatolia are more likely to exit from unemployment to out-of-the labor force compared to women who live in Central Anatolia. With regards to the different levels of education we observe the following results. For men on the transition from unemployment to employment the marginal effects are mostly positive and statistically significant when occupation dummies are excluded. These results imply that increasing levels of education increase the likelihood of getting a job from unemployment. For women, the same marginal effects are positive and statistically significant only for the university level education implying that tertiary level of education increase the likelihood of getting a job from unemployment compared to the base category of non-graduates. For both men and women, the marginal effects of different levels of education on the transition from unemployment to out-of-the labor force are negative and mostly significant implying that more educated men and women are less likely to exit from unemployment to out-of-the labor force compared to non-graduates.

When we consider effects of age, we observe that for men and women both the marginal effects of age on transition from unemployment to employment are negative and statistically significant after age 35 . This implies that increases in age reduce the likelihood of getting a job from unemployment for both men and women compared to the base category of age 15-19. For men, the marginal effects of age categories on the transition from unemployment to out-of-the labor force are negative and mostly significant when the occupation dummies are excluded. The same 
marginal effects for women are statistically insignificant. These results imply that for men increases in age reduce the likelihood of going from unemployment to out-ofthe labor force, except for men in their late careers. Examining the marginal effects of the local unemployment rate on the transition from unemployment to employment we observe that for men they are negative and statistically significant while for women negative and statistically significant when occupational dummies are included. These results imply that men and women who live in high unemployment provinces are less likely to obtain a job from unemployment. For both men and women the marginal effects of local unemployment rate on the transition from unemployment to out-of-the labor force are statistically insignificant.

With regards to occupational groups, we observe that for men the marginal effects on transition from unemployment to employment are all positive and statistically significant except for occupation 2 which is administrative and managerial workers. This suggests that for all of the occupational categories (except for occupation 2) men are more likely to go from unemployment to employment compared to the base category of professional and related workers. For women the same marginal effects are positive and mostly statistically significant. The results imply that women clerical and related workers (occupation 3), service workers (occupation 5) and non-agricultural workers (occupation 7) are more likely to find a job from unemployment compared to the base category of professional and related workers. For men and women both, the marginal effects on the transition from unemployment to out-of-the labor force are all negative and statistically significant. The results imply that men and women both in all of the occupational categories are less likely to go from unemployment to out-of-the labor force compared to the 
professional and related workers. We now consider the results for the employment status. For men, most of the marginal effects on the transition from unemployment to employment are positive and statistically significant. These results imply that employers (status 4), self employed (status 5) and unpaid family workers (status 6) are more likely to get a job from unemployment compared to the base category of regular employees. The same marginal effects for women are all statistically insignificant except for casual employees (status 2). The negative marginal effect implies that casual employees are less likely to find a job from unemployment. For men, most of the marginal effects on transition from unemployment to out-of-the labor force are insignificant except for self-employed (status 5) and unpaid family workers (status 6). These estimates are negative and imply that self-employed and unpaid family worker men are less likely to go out-of-the labor force from unemployment compared to the base category of regular employees. The same marginal effects for women are mostly insignificant except for casual employees (status 2) and self-employed (status 5). These estimates are negative and imply that casual employee and self-employed women are less likely to go from unemployment to out-of-the labor force.

In order to capture the duration dependence effect, we have included dummy variables for unemployment duration in the models. For men, the marginal effects on the transition from unemployment to employment are mostly statistically insignificant except for duration 6-12 months. The negative marginal effect implies that the likelihood of obtaining a job from unemployment is lower for duration 6-12 months compared to the base category of duration 1-3 months. The same marginal effects for women are all negative and statistically significant when occupational 
dummies are excluded. These results imply that for women the likelihood of getting a job from unemployment declines with increases in unemployment duration. Thus, there is negative duration dependence. For men, most of the marginal effects of transition from unemployment to out-of-the labor force are positive and significant implying that the likelihood of going from unemployment to out-of-the labor force increases with unemployment duration. The same marginal effects for women are all statistically insignificant. The results for men suggest that there is a "discouraged worker effect". Finally, we examine the effects of job search methods. For men and women both the marginal effects on the transition from unemployment to employment are mostly statistically significant. For men using "newspapers" and "workers agents and mediators" increases the likelihood of getting a job from unemployment. For both men and women the job search channels of "try to provide equipment, credit and place to establish own business" and "other methods" reduce the likelihood of getting a job from unemployment. For women, the "employment office" also reduces the likelihood of getting a job from unemployment compared to the base category of personal job search. For men, most of the marginal effects on transition from unemployment to out-of-the labor force are negative. For men, the results imply that "employment office", "try to provide equipment, credit and place to establish own business" and "other methods" reduce the likelihood of going from unemployment to out-of-the labor force. The statistically insignificant results for women imply that the various job search channels are not different from the base category of personal job search. Overall the results suggest that for men the newspapers and workers agents are the most useful job search strategies. 


\subsection{The Determinants of Transitions from Out-of-the Labor Force}

In this section we discuss the determinants of transitions from out-of-the labor force to employment and unemployment. The estimation results are reported in Table 12 separately for men and women. The variables included are the same as those in the transitions from employment. For men, the marginal effects of living in urban areas on the transition from out-of-the labor force to employment are statistically insignificant. The same marginal effects for women are negative and statistically significant implying that the likelihood of getting a job from out-of-the labor force is lower for urban women. For men the marginal effects of living in urban areas on the transition from out-of-the labor force to unemployment are insignificant while for women they are positive and significant implying that urban women are more likely to move from out-of-the labor force to unemployment. Considering the effects of being married we observe that for men the marginal effects are positive and significant when the occupation dummies are excluded implying that marriage increases the likelihood of finding a job from out-of-the labor force. The same marginal effects for women are negative and statistically significant implying that marriage reduces the likelihood of finding a job from out-of-the labor force. We note the opposite effects of marriage for men and women. For men, the marginal effects of marriage on the transition from out-of-the labor force to unemployment are statistically insignificant while for women they are positive and significant. These results imply that married women are more likely to move from out-of-the labor force to unemployment.

When we consider the effects of living in different regions we observe that for men the marginal effects of the transitions from out-of-the labor force to 
employment are positive and significant for Marmara and South East Anatolia but negative and significant for Aegean. These results imply that men who live in Marmara and South East Anatolia are more likely and those who live in Aegean are less likely to find a job from out-of-the labor force as compared to those who live in the base region of Central Anatolia. The same marginal effects for women are mostly statistically significant. The results imply that women who live in Marmara, Aegean, Black Sea and East Anatolia are less likely to exit from out-of-the labor force to employment, but, women who live in South East Anatolia are more likely to exit from out-of-the labor force to employment. With regards to transitions from out-ofthe labor force to unemployment, the marginal effects for men are all statistically insignificant and those for women are insignificant in magnitude. When we consider the different levels of education we observe that for men, on the transition from outof-the labor force to employment the marginal effects are mostly significant. The results imply that the likelihood of exiting out-of-the labor force to employment is higher for primary school, vocational high school, and four-year university graduates but lower for middle school graduates. The same marginal effects for women are positive and mostly significant implying that higher levels of education increase the likelihood of exiting out-of-the labor force to employment. For men the marginal effects on transition from out-of-the labor force to unemployment are all statistically insignificant while for women they are mostly significant and imply that increasing levels of education increase the likelihood of exiting out-of-the labor force to unemployment.

With regards to effects of age we observe that the marginal effects of age for men (after age 45) and for women are all negative and statistically significant 
implying that increases in age reduce the likelihood of exiting out-of-the labor force to employment compared to the base category of age 15-19. The marginal effects of age on transition from out-of-the labor force to unemployment are statistically significant and negative after age 44 implying that for men increases in age reduce the likelihood of exiting out-of-the labor force for unemployment. The same marginal effects for women are mostly insignificant in magnitude. Examining the marginal effects of the local unemployment rate on the transition from out-of-the labor force to employment we observe that for both men and women they are negative and statistically significant implying that men and women who live in high unemployment provinces are less likely to obtain a job from out-of-the labor force. For both men and women the marginal effects of local unemployment rate on the transition from out-of-the labor force to unemployment are statistically insignificant.

With regards to occupational groups we observe that for both men and women the marginal effects on transition from out-of-the labor force to employment are all positive and statistically significant. These results suggest that for all of the occupational categories men and women both are more likely to obtain a job from out-of-the labor force compared to the base category of professional and related workers. For both men and women the marginal effects on the transition from out-ofthe labor force to unemployment are mostly insignificant. We now consider the results for the employment status. For both men and women most of the marginal effects of employment statuses on the transition from out-of-the labor force to employment are all positive and statistically significant. The results imply that all of the individuals in different employment statuses are more likely to get a job from out-of-the labor force compared to the base category of regular employees. As for the 
transition from out-of-the labor force to unemployment most of the marginal effects are statistically insignificant for both men and women.

\section{Concluding Remarks}

In this paper, we examine the labor market transitions in Turkey by using the HLFS data. In the first part, we analyze the transition probabilities between the labor market states of employment, unemployment, and out-of-the-labor force under Markovian assumptions. We analyze the sources of unemployment rate differentials for gender, rural-urban residence and marital status, by using the Marston's (1976) decomposition. In the second part of the study, we further analyze the transitions in the Turkish labor market by estimating multinomial logit models. In this part we concentrate on the role of individual characteristics. These include age, education and other determinants, such as, region, occupation and status in employment. The main findings of the study are summarized in this section.

For designing policy tools in order to reduce the unemployment rate differentials among the labor market groups it may be useful to have an idea about the differentials in the following six transition probabilities (Lauerova and Terrell, 2002). These are $P_{\text {eu }}, P_{\text {eo }}, P_{u e}, P_{u o}, P_{o u}, P_{o e}$. For example, for non-married individuals, the most important factor explaining their higher unemployment rates are that they are less likely to enter the labor market successfully than the married individuals, and they are more likely to leave (quit or lose) their jobs for unemployment $\left(\mathrm{P}_{\mathrm{eu}}\right)$. The main factors behind the unemployment rate differential between women and men in the urban areas are as follows. The first is the probability of exiting from employment for unemployment $\left(\mathrm{P}_{\mathrm{eu}}\right)$ for urban women is larger than those of urban 
men. The second is the probability that women leave unemployment for a job $\left(\mathrm{P}_{\mathrm{ue}}\right)$ is lower than men's. Thus, due to the above factors the rate of unemployment is considerably higher for the urban women than urban men. This observed unemployment rate differential can be considered one of the factors behind the female's lower labor force participation in the urban areas (Tansel, 2002; Tunali, 2003). Our findings support this since most of the job loser women go to out-of-the labor force. Hence, because of the economic crisis most of the job-loser urban women become discouraged. In this regard, Turkish policy makers might consider creating a policy tool to increase women's participation rate. A further policy tool might be developed to increase women's chances of obtaining a job from unemployment. Another policy tool might focus on reducing the women's higher risk of losing job relative to men.

Let us now consider the estimation results of the multinomial logit model. It is found that for both men and women, there is a significant difference between the education groups in the probability of becoming unemployed from employment. For men, we observe that the university educated individuals are less likely to go both to unemployment and to out-of-the labor force compared to illiterates and nongraduates. However, for women increases in the education level does not affect the transition from employment to unemployment. While educated women are less likely to go from employment to out-of-the labor force compared to illiterates and nongraduates. A further finding is that men and women with a university degree are more likely to find a job from unemployment compared to non-graduates. However, having a vocational high school diploma does not make any significant difference in obtaining a job from unemployment. Hence, human capital effect is seen only for the 
university graduates. This finding is also supported by the estimation results of transitions from out-of-the labor force to employment. Four-year university education increases the likelihood of exiting from out-of-the labor force to employment. Further, younger individuals are more likely to lose a job but older individuals are less likely to find a job from unemployment.

We used the provincial level unemployment rate as a proxy for labor market conditions. We found significant and expected marginal effects for each gender in the cases of $\mathrm{P}_{\mathrm{eo}} \mathrm{P}_{\mathrm{ue}}$ and $\mathrm{P}_{\mathrm{oe}}$. In the other transition case of $\mathrm{P}_{\mathrm{uo}}$, this variable is not significant for men and women. These results imply that men and women who live in high unemployment provinces are more likely to lose their jobs and less likely to obtain a job from unemployment. Policy makers could concentrate on improving the unemployment rates in the high unemployment provinces. Further, increasing labor mobility between provinces could increase the likelihood of finding a job.

One of the important findings is that casual employees are more likely to lose their work compared to regular employees. Regarding the employment sector the most striking result is that the marginal effect of the public sector variable on the transitions from employment is negative and highly significant suggesting that workers in the public sector are less likely to become unemployed. The findings, on casual and non-public sector employees, imply that these groups are more likely to lose their job compared to other groups. Therefore, they may be considered as special target group by the policy makers. Regarding the unemployment duration parameters in the transitions from unemployment to employment, in general, we found the expected marginal effects. However, they were significant only for women implying 
negative duration dependence which means that the likelihood of getting a job from unemployment declines with increases in unemployment duration.

Finally, for the job search methods in $\mathrm{P}_{\mathrm{ue}}$ equation, we found negative significant effect for "try to provide equipment, credit, place to establish own business" and positive effect comes from "newspaper" and "workers agent and mediators" variable compared to "personally job seekers" for men. If we look at the $\mathrm{P}_{\mathrm{u}}$ equation for men, the negative and significant effects only comes from "employment office", "workers agents" and "other" variables. Therefore, it is possible to say that although the "employment office" variable does not contribute to finding a job for unemployed men, it ties them to the labor force. However, all of the job search method dummies are insignificant in the transition from unemployment to out-of-the labor force in the female equations. Overall, the results suggest that for men the newspapers and workers agents are the most useful job search strategies. 


\section{REFERENCES}

Bellmann, L., S. Estrin and J. Svejnar (1995), "The Eastern German labor market in transition: gross flow estimates from panel data", Journal of Comparative Economics 20,139-170.

DeBoer, L. and M. C. Seeborg (1989), "The Unemployment Rates of Men and Women a Transition Probability Analysis", Industrial and Labor Relations Review, 42(3), 404-414.

Devine, T.J. and N.M. Kiefer (1991), Empirical Labor Economics, Oxford University Press: Oxford.

Foley, Mark C. (1997a), "Labor Market Dynamics in Russia", Economic Growth Center: Center Discussion Paper no. 780, New Haven: Yale University.

Francesconi, M. (1999), "Labor Force Transitions among Married Women in the USA”, Labour, 13(4), 775-796.

Greene, W. H. (1994), Econometric Analysis, New Jersey, Prentice-Hall.

Grogan, L. (2000), “Worker Flows in Russia”, Tinbergen Institute Discussion Paper, no:2000-08/3.

Huitfeldt, H. (1996), "Unemployment and Labor Market Transitions in the Czech Republic: Evidence from Micro-Data”, Unpublished Manuscript, Uppsala University, Sweden.

Lauerova, J.S. and K. Terrel (2002), "Explaining Gender Differences in Unemployment with Micro Data on Flows in Post-Communist Economies", IZA Discussion Paper No.600.

Marston, S.T., (1976), "Employment Instability and High Unemployment Rates", Brookings Papers on Economic Activity, 1, 169-203.

Nielsen, O.A., A.E. Risa and A.Torstensen (2000), “Transitions from Employment among Young Norwegian Workers", Journal of Population Economics, 13, 21-34.

OECD Database (2004), OECD Databases on Labor Force Statistics, URL address: http://www.oecd.org, last accessed September 20, 2004.

State Institute of Statistics (SIS) (2001a), Household Labor Force Survey Results 2000, October 2001, Ankara: State Institute of Statistics.

State Institute of Statistics (SIS) (2001b), Hanehalkı İsgücü Anketi: Kavramlar ve Yöntemler (Household Labor Force Survey: Concepts and Methods), September 2001, Ankara: State Institute of Statistics, Publication No.2484.

State Institute of Statistics (SIS) (2003), Statistical Indicators, 1923-2002, SIS, 
Ankara-Turkey.

State Institute of Statistics (SIS) Database (2004), Household Labor Force Survey

Database (Hanehalkı İşü̈cü Anketi Veritabanı), URL address: http://www.die.gov.tr, last accessed December 20, 2004.

State Institute of Statistics (SIS) (2005), News Letter: Household Labor Force Survey Results of 2004, (Hanehalkı Isşü̈cü Anketi 2004 Yılı Sonuçlarl, 30 Mart 2005), 30 March 2005, URL address: http://www.die.gov.tr, last accessed May 30, 2005.

Stromback, T., M. Dockery and W. Ying (1998), "Transitions in the Labour Market: Evidence from the Survey of Employment and Unemployment Patterns", Melborne Institute Working Paper, No.1/98.

Tansel, A. (2002), "Economic Development and Female Labor Force Participation in Turkey: Time Series Evidence and Cross-Province Estimates", in Employment of Women ed. by Tuncer Bulutay, Statte Institute of Statistics, Ankara.

Taşçı, H. M. (2005), "Essays on Unemployment in Turkey" Unpublished PhD Thesis, Middle East Technical University, Ankara.

Theeuwes, J., M. Kerkhofs and M. Lindeboom (1990), "Transition Intensities in the Dutch Labour Market 1980-85”, Applied Economics, 22, 1043-1061.

Tunali, İ. (2003), Background Study on Labor Market and Employment in Turkey, Prepared for the European Training Foundation, June-2003, Ankara-Turkey.

Wolterman, S. (2002), "Job-Search Methods and Labor Market Transitions in a Segmented Economy: Some Empirical Evidence from Brazil", Ibero-America Institute for Economic Research, Discussion Paper No:88, University of Göttingen. 
Table 1: Demographic Differences between Individuals in Different Labor Market States in the First Quarters

\begin{tabular}{|c|c|c|c|}
\hline a) 2000 & $\begin{array}{c}\text { Employment (in \% of } \\
\text { the population) }\end{array}$ & $\begin{array}{l}\text { Unemployment (in \% } \\
\text { of the labor force) }\end{array}$ & $\begin{array}{l}\text { Out of Labor Force (in } \\
\% \text { of the population) }\end{array}$ \\
\hline All & 38.93 & 9.09 & 57.18 \\
\hline 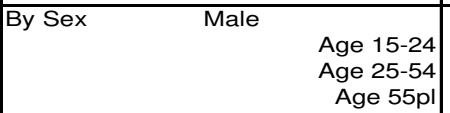 & $\begin{array}{l}62.72 \\
36.67 \\
79.62 \\
40.30\end{array}$ & $\begin{array}{c}8.19 \\
17.11 \\
6.89 \\
3.71\end{array}$ & $\begin{array}{l}31.42 \\
55.76 \\
14.49 \\
58.15\end{array}$ \\
\hline $\begin{array}{rr}\text { Female } & \\
& \text { Age 15-24 } \\
& \text { Age 25-54 } \\
\text { Age 55pl }\end{array}$ & $\begin{array}{l}16.37 \\
16.04 \\
17.69 \\
10.31\end{array}$ & $\begin{array}{c}9,61 \\
20.69 \\
6.88 \\
0.74\end{array}$ & $\begin{array}{l}81.61 \\
79.77 \\
81.00 \\
89.62\end{array}$ \\
\hline $\begin{array}{r}\text { Urban-Male } \\
\text { Rural-Male } \\
\text { Urban-Female } \\
\text { Rural-Female }\end{array}$ & $\begin{array}{l}45.40 \\
36.90 \\
62.15 \\
64.54 \\
13.01 \\
27.12\end{array}$ & $\begin{array}{c}5.79 \\
10.30 \\
9.02 \\
7.07 \\
15.68 \\
2.74\end{array}$ & $\begin{array}{l}51.81 \\
58.87 \\
31.69 \\
30.56 \\
84.57 \\
72.12\end{array}$ \\
\hline $\begin{array}{r}\text { Non-Graduate } \\
\text { Primary School } \\
\text { Middle School } \\
\text { High School } \\
\text { Voc. High School } \\
\text { Two-Years University } \\
\text { Four Years University }\end{array}$ & $\begin{array}{l}20.16 \\
40.32 \\
32.47 \\
41.29 \\
56.75 \\
65.29 \\
76.30\end{array}$ & $\begin{array}{c}6.68 \\
9.11 \\
9.76 \\
11.18 \\
12.24 \\
10.48 \\
3.72 \\
\end{array}$ & $\begin{array}{l}78.40 \\
55.64 \\
64.02 \\
53.52 \\
35.33 \\
27.07 \\
20.75\end{array}$ \\
\hline $\begin{array}{r}\text { Married Male } \\
\text { Non-Married Male } \\
\text { Married Female } \\
\text { Non-Married Female }\end{array}$ & $\begin{array}{l}29.38 \\
43.50 \\
\\
74.17 \\
39.24 \\
14.76 \\
19.79\end{array}$ & \begin{tabular}{c|}
17.37 \\
6.04 \\
\\
6.15 \\
16.77 \\
5.54 \\
18.51
\end{tabular} & $\begin{array}{l}64.44 \\
53.70 \\
\\
20.97 \\
52.85 \\
84.38 \\
75.71 \\
\end{array}$ \\
\hline b) 2001 & $\begin{array}{l}\text { Employment (in \% of } \\
\text { the population) }\end{array}$ & $\begin{array}{l}\text { Unemployment (in \% } \\
\text { of the labor force) }\end{array}$ & $\begin{array}{l}\text { Out of Labor Force (in } \\
\% \text { of the population) }\end{array}$ \\
\hline All & 39.32 & 10.38 & 56.12 \\
\hline $\begin{array}{l}\text { Male } \\
\text { Age 15-24 } \\
\text { Age 25-54 } \\
\text { Age 55pl }\end{array}$ & $\begin{array}{l}64.14 \\
37.83 \\
80.24 \\
41.30\end{array}$ & $\begin{array}{c}9.28 \\
20.31 \\
7.11 \\
3.64\end{array}$ & $\begin{array}{l}29.30 \\
52.52 \\
13.62 \\
57.14\end{array}$ \\
\hline $\begin{array}{rr}\text { Female } & \\
& \text { Age 15-24 } \\
& \text { Age 25-54 } \\
\text { Age 55pl }\end{array}$ & $\begin{array}{c}16.01 \\
15.52 \\
17.39 \\
9.81\end{array}$ & $\begin{array}{c}14.29 \\
24.85 \\
10.19 \\
0.81\end{array}$ & $\begin{array}{l}81.32 \\
79.34 \\
80.63 \\
90.10\end{array}$ \\
\hline $\begin{array}{r}\text { Urban-Male } \\
\text { Rural-Male } \\
\text { Urban-Female } \\
\text { Rural-Female }\end{array}$ & $\begin{array}{l}46.04 \\
37.26 \\
63.31 \\
66.87 \\
12.63 \\
26.89\end{array}$ & $\begin{array}{c}6.86 \\
11.62 \\
9.73 \\
7.78 \\
19.58 \\
4.69\end{array}$ & $\begin{array}{l}50.57 \\
57.83 \\
29.85 \\
27.49 \\
84.29 \\
71.79\end{array}$ \\
\hline \begin{tabular}{|} 
Non-Graduate \\
Primary School \\
Middle School \\
High School \\
Voc.High School \\
Two-Years University \\
Four Years University
\end{tabular} & $\begin{array}{l}21.67 \\
40.06 \\
31.38 \\
43.16 \\
54.46 \\
61.02 \\
77.37 \\
\end{array}$ & $\begin{array}{c}6.07 \\
9.88 \\
12.26 \\
15.20 \\
13.47 \\
6.90 \\
4.81\end{array}$ & $\begin{array}{l}76.93 \\
55.55 \\
64.23 \\
49.11 \\
37.06 \\
34.46 \\
18.72\end{array}$ \\
\hline $\begin{array}{r}\text { Married Male } \\
\text { Non-Married Male } \\
\text { Married Female } \\
\text { Non-Married Female }\end{array}$ & $\begin{array}{l}29.54 \\
43.86 \\
\\
75.05 \\
40.78 \\
14.68 \\
18.89\end{array}$ & $\begin{array}{c}21.02 \\
6.44 \\
\\
6.31 \\
19.36 \\
7.07 \\
24.20\end{array}$ & $\begin{array}{l}62.60 \\
53.12 \\
\\
19.90 \\
49.43 \\
84.20 \\
75.08\end{array}$ \\
\hline
\end{tabular}


Table 2: Demographic Differences between Individuals in Different Labor Market States in the Second Quarters

\begin{tabular}{|c|c|c|c|}
\hline a) 2000 & $\begin{array}{l}\text { Employment (in \% of the } \\
\text { population) }\end{array}$ & $\begin{array}{c}\text { Unemployment (in \% } \\
\text { of the labor force) }\end{array}$ & $\begin{array}{l}\text { Out of Labor Force (in } \\
\% \text { of the population) }\end{array}$ \\
\hline All & 43.73 & 6.90 & 53.03 \\
\hline $\begin{array}{r}\text { Age } 15-24 \\
\text { Age } 25-54 \\
\text { Age } 55 \mathrm{pl}\end{array}$ & $\begin{array}{c}69.04 \\
43.44 \\
85.21 \\
44.82\end{array}$ & $\begin{array}{c}6.19 \\
13.90 \\
4.48 \\
3.63\end{array}$ & $\begin{array}{l}26.40 \\
49.55 \\
10.79 \\
53.49\end{array}$ \\
\hline Female & 20.04 & 9.13 & 77.94 \\
\hline Age 15-24 & 19.30 & 14.93 & 77.31 \\
\hline Age 25-54 & 21.68 & 7.30 & 76.61 \\
\hline Age 55pl & 13.57 & 1.10 & 86.27 \\
\hline \multirow{2}{*}{$\begin{array}{l}\text { Rural } \\
\text { Urban }\end{array}$} & 56.18 & 2.70 & 42.26 \\
\hline & 39.76 & 8.68 & 56.47 \\
\hline Urban-Male & 66.44 & 7.19 & 28.42 \\
\hline Rural-Male & 77.24 & 3.36 & 20.07 \\
\hline Urban-Female & 14.77 & 14.46 & 82.73 \\
\hline Rural-Female & 36.54 & 1.37 & 62.95 \\
\hline \multicolumn{4}{|l|}{ Education } \\
\hline Non-Graduate & 26.16 & 4.63 & 72.57 \\
\hline Primary School & 45.42 & 6.01 & 51.67 \\
\hline Middle School & 35.91 & 8.97 & 60.55 \\
\hline High School & 46.05 & 9.57 & 49.08 \\
\hline Voc.High School & 57.46 & 9.83 & 36.28 \\
\hline Two-Years University & 70.74 & 7.78 & 23.30 \\
\hline Four Years University & 77.52 & 4.83 & 18.55 \\
\hline \multirow{2}{*}{$\begin{array}{l}\text { Non-Married } \\
\text { Married }\end{array}$} & 34.21 & 13.97 & 60.24 \\
\hline & 48.19 & 4.28 & 49.65 \\
\hline \multirow{4}{*}{$\begin{array}{r}\text { Married Male } \\
\text { Non-Married Male } \\
\text { Married Female } \\
\text { Non-Married Female } \\
\end{array}$} & 80.15 & 3.83 & 16.66 \\
\hline & 45.61 & 14.01 & 46.96 \\
\hline & 18.49 & 6.09 & 80.31 \\
\hline & 23.39 & 13.89 & 72.84 \\
\hline b) 2001 & $\begin{array}{c}\text { Employment (in \% of the } \\
\text { population) }\end{array}$ & $\begin{array}{c}\text { Unemployment (in \% } \\
\text { of the labor force) }\end{array}$ & $\begin{array}{l}\text { Out of Labor Force (in } \\
\% \text { of the population) }\end{array}$ \\
\hline All & 42.57 & 8.27 & 53.59 \\
\hline \multirow[t]{2}{*}{ Sex } & & & \\
\hline & 66.80 & 7.57 & 27.73 \\
\hline Age 15-24 & 40.94 & 15.33 & 51.65 \\
\hline Age $25-54$ & 82.70 & 6.06 & 11.97 \\
\hline Age 55pl & 42.56 & 3.94 & 55.69 \\
\hline Female & 20.13 & 10.36 & 77.54 \\
\hline Age 15-24 & 18.40 & 19.37 & 77.18 \\
\hline Age 25-54 & 22.13 & 7.33 & 76.12 \\
\hline Age 55pl & 14.02 & 0.56 & 85.91 \\
\hline \multirow{2}{*}{$\begin{array}{l}\text { Rural } \\
\text { Urban }\end{array}$} & 57.03 & 3.12 & 41.14 \\
\hline & 38.05 & 10.50 & 57.48 \\
\hline Urban-Male & 64.05 & 8.76 & 29.79 \\
\hline Rural-Male & 75.61 & 4.18 & 21.09 \\
\hline Urban-Female & 13.96 & 17.21 & 83.14 \\
\hline Rural-Female & 39.87 & 1.21 & 59.64 \\
\hline Education & & & \\
\hline Non-Graduate & 26.82 & 6.02 & 71.46 \\
\hline Primary School & 44.23 & 7.25 & 52.32 \\
\hline Middle School & 32.62 & 9.71 & 63.87 \\
\hline High School & 44.05 & 12.19 & 49.84 \\
\hline Voc.High School & 58.54 & 11.74 & 33.67 \\
\hline Two-Years University & 62.47 & 8.06 & 32.05 \\
\hline Four Years University & 75.87 & 5.39 & 19.81 \\
\hline \multirow{2}{*}{$\begin{array}{l}\text { Non-Married } \\
\text { Married }\end{array}$} & $\begin{array}{l}32.09 \\
47.44\end{array}$ & $\begin{array}{l}16.62 \\
5.29\end{array}$ & $\begin{array}{l}61.51 \\
49.91\end{array}$ \\
\hline & 47.44 & 5.29 & 49.91 \\
\hline Married Male & 77.53 & 5.26 & 18.17 \\
\hline Non-Married Male & 43.74 & 15.43 & 48.28 \\
\hline Married Female & 19.59 & 5.39 & 79.30 \\
\hline Non-Married Female & 21.31 & 18.80 & 73.76 \\
\hline
\end{tabular}




\section{Table 3: List of the Variables}

1. "Urban" is a dummy variable taking value 1 if a man or woman lives in a town of more than 20,000 inhabitants and 0 otherwise

2. "Married" is a dummy variable taking value 1 if the survey respondent is married and 0 otherwise

3. Region of residence is a set of seven dummies: Central Anatolia (base category), Marmara, Aegean, Mediterranean Black Sea, East Anatolia, and South East Anatolia.

4. Education consists of a set of six dummies: The reference category includes those who are illiterate plus those who are literate but did not graduate from a school. The other education categories are "Primary School",

"Middle School", "High School", "Vocational High School", "Two-Year University", and "Four-Year University and over" ("Univ4pl").

5. Age is a set of six dummies:

"age1519": Age 15-19 (base category)

"age2024": Age 20-24

"age2534": Age 25-34

"age3544": Age 35-44

"age4554": Age 45-54

"age55pl": Age 55 and over.

6. "Unemprate" is the provincial unemployment rate.

7. Occupation in the job (last job for the unemployed persons) consists of eight dummies:

"occup1": Professional and related workers (base category),

"occup2": Administrative and managerial workers

"occup3": Clerical and Related Workers,

"occup4": Sales Workers,

"occup5": Service Workers,

"occup6": Agricultural Workers,

"occup7": Non-Agricultural Workers

"occup8": Workers not classified by Occupation

8. Status in the current job (last job for the unemployed persons) consists of six dummies:

"status 1": Regular Employee (base category)

"status2": Casual Employee

"status3": Paid family Workers

"status4": Employer

"status5": Self Employed

"status6": Unpaid Family Workers

Variable(s) used only in transitions from employment:

9. Public Sector dummy takes value 1 if an individual works in the public sector, 0 (zero) otherwise.

Variables used only in transitions from unemployment:

10. Search Method dummies takes value 1 if used by an unemployed individual. The reference category includes those who are "personally job-seeking". Other Job-search methods are; "Friendsetc" (Friends and relatives", "Newspapers", "Employment Office", "Workersagent" (Workers agents and mediators), "Trytoprovideequipment" (try to provide equipment, credit and place to establish own business), and "Other methods".

11. Duration of unemployment is set of five dummies. Takes value of one if the duration of unemployment lies into that group; duration 1-3 (month) (base category), duration 4-6, duration 7-12, duration 13-24, duration 24 plus. 
Table 4: Transition Probabilities between the First Quarters of 2000 and 2001 (\%)

\begin{tabular}{|c|c|c|c|c|c|c|c|c|c|}
\hline & Peu & Pee & Peo & Puu & Pue & Puo & Pou & Poe & Poo \\
\hline All & 3.48 & 79.47 & 17.04 & 46.23 & 45.66 & 8.11 & 2.28 & 11.56 & 86.16 \\
\hline \multicolumn{10}{|l|}{ By Sex } \\
\hline Male & 3.81 & 86.15 & 10.04 & 39.68 & 55.87 & 4.45 & 5.15 & 22.89 & 71.96 \\
\hline Female & 2.13 & 61.40 & 36.47 & 73.84 & 19.77 & 6.40 & 1.16 & 6.69 & 92.15 \\
\hline \multicolumn{10}{|l|}{ By Place } \\
\hline Urban & 3.87 & 82.10 & 14.04 & 47.33 & 45.44 & 7.23 & 2.46 & 8.72 & 88.82 \\
\hline Rural & 2.56 & 73.23 & 24.21 & 40.98 & 46.72 & 12.30 & 1.60 & 22.00 & 76.40 \\
\hline \multicolumn{10}{|l|}{ By Urban-Male } \\
\hline Urban-Male & 3.98 & 86.99 & 9.03 & 40.45 & 55.53 & 4.02 & 5.36 & 19.49 & 75.14 \\
\hline Rural-Male & 3.31 & 83.70 & 12.99 & 36.46 & 57.29 & 6.25 & 4.40 & 34.42 & 61.17 \\
\hline Urban-Female & 2.93 & 66.14 & 30.93 & 72.73 & 21.43 & 5.84 & 1.38 & 4.23 & 94.39 \\
\hline Rural-Female & 1.09 & 55.33 & 43.58 & 83.33 & 5.56 & 11.11 & 0.30 & 16.21 & 83.48 \\
\hline \multicolumn{10}{|l|}{ Marital Status } \\
\hline Non-Married & 6.91 & 66.56 & 26.53 & 49.83 & 35.64 & 14.52 & 4.52 & 13.47 & 82.01 \\
\hline Married & 2.42 & 83.43 & 14.14 & 45.45 & 52.34 & 2.20 & 1.10 & 10.04 & 88.86 \\
\hline \multicolumn{10}{|l|}{ By Married-Male } \\
\hline Married-Male & 2.89 & 88.72 & 8.39 & 39.93 & 58.75 & 1.32 & 3.77 & 25.50 & 70.73 \\
\hline Non-Married-Male & 7.86 & 73.69 & 18.45 & 42.07 & 47.56 & 10.37 & 6.49 & 18.61 & 74.90 \\
\hline Married-Female & 0.44 & 60.74 & 38.82 & 75.44 & 21.05 & 3.51 & 0.47 & 6.37 & 93.16 \\
\hline Non-Married-Female & 5.63 & 65.44 & 28.93 & 73.64 & 19.09 & 7.27 & 3.07 & 7.26 & 89.67 \\
\hline \multicolumn{10}{|l|}{ Age Group } \\
\hline Age15-19 & 6.78 & 58.19 & 35.03 & 53.61 & 30.93 & 15.46 & 3.25 & 11.80 & 84.96 \\
\hline Age20-24 & 5.58 & 72.32 & 22.10 & 44.53 & 47.66 & 7.81 & 4.76 & 12.50 & 82.74 \\
\hline Age25-34 & 4.50 & 85.86 & 9.64 & 46.81 & 50.35 & 2.84 & 2.49 & 10.22 & 87.29 \\
\hline Age35-44 & 2.25 & 88.10 & 9.65 & 46.23 & 52.83 & 0.94 & 1.87 & 9.64 & 88.49 \\
\hline Age $45-54$ & 1.86 & 80.46 & 17.68 & 55.71 & 42.86 & 1.43 & 1.03 & 11.00 & 87.97 \\
\hline Age55pl & 0.34 & 70.18 & 29.48 & 47.06 & 52.94 & 0.00 & 0.18 & 8.19 & 91.63 \\
\hline \multicolumn{10}{|l|}{ By Age Group- MALE- } \\
\hline Age15-19 & 6.69 & 69.60 & 23.71 & 43.33 & 41.67 & 15.00 & 4.25 & 16.55 & 79.20 \\
\hline Age20-24 & 7.44 & 78.51 & 14.05 & 39.24 & 59.49 & 1.27 & 12.02 & 24.04 & 63.94 \\
\hline Age25-34 & 5.17 & 90.09 & 4.74 & 38.14 & 60.82 & 1.03 & 14.50 & 46.56 & 38.93 \\
\hline Age35-44 & 2.66 & 93.12 & 4.22 & 37.78 & 61.11 & 1.11 & 13.24 & 45.59 & 41.18 \\
\hline Age45-54 & 2.25 & 84.71 & 13.05 & 50.79 & 47.62 & 1.59 & 4.16 & 22.60 & 73.25 \\
\hline Age55pl & 0.43 & 75.59 & 23.97 & 50.00 & 50.00 & 0.00 & 0.47 & 13.06 & 86.47 \\
\hline \multicolumn{10}{|l|}{ By Age Group- FEMALE- } \\
\hline Age15-19 & 9.03 & 49.31 & 41.67 & 80.65 & 12.90 & 6.45 & 2.38 & 6.63 & 90.99 \\
\hline Age20-24 & 3.08 & 68.21 & 28.72 & 65.00 & 25.00 & 10.00 & 2.44 & 7.16 & 90.40 \\
\hline Age25-34 & 1.37 & 70.96 & 27.67 & 69.05 & 28.57 & 2.38 & 1.47 & 6.35 & 92.18 \\
\hline Age35-44 & 0.52 & 66.58 & 32.90 & 93.75 & 6.25 & 0.00 & 0.86 & 6.39 & 92.75 \\
\hline Age $45-54$ & 100.00 & 0.00 & 0.00 & 0.00 & 59.79 & 40.21 & 0.00 & 7.11 & 92.89 \\
\hline Age55pl & 0.00 & 51.49 & 48.51 & 0.00 & 100 & 0.00 & 0.00 & 5.03 & 94.97 \\
\hline \multicolumn{10}{|l|}{ Education Group } \\
\hline Non-Graduate & 1.16 & 64.92 & 33.91 & 43.75 & 47.92 & 8.33 & 0.45 & 9.09 & 90.47 \\
\hline Primary & 4.20 & 79.11 & 16.69 & 43.70 & 49.58 & 6.72 & 1.73 & 10.87 & 87.40 \\
\hline Middle School & 3.72 & 81.73 & 14.55 & 44.19 & 51.16 & 4.65 & 2.37 & 6.86 & 90.76 \\
\hline High School & 2.89 & 88.45 & 8.66 & 63.30 & 25.69 & 11.01 & 5.36 & 12.18 & 82.46 \\
\hline Voc. High School & 3.55 & 91.13 & 5.32 & 53.57 & 32.14 & 14.29 & 7.51 & 12.72 & 79.77 \\
\hline Two-Year University & 1.92 & 91.35 & 6.73 & 17.24 & 72.41 & 10.34 & 2.22 & 11.11 & 86.67 \\
\hline Four-Year Un.and over & 1.10 & 94.12 & 4.78 & 38.89 & 50.00 & 11.11 & 3.33 & 15.00 & 81.67 \\
\hline Number of Transitions & 272 & 6206 & 1330 & 326 & 320 & 57 & 254 & 1288 & 9600 \\
\hline Number of Observations & 7808 & 7808 & 7808 & 703 & 703 & 703 & 11142 & 11142 & 11142 \\
\hline
\end{tabular}


Table 5: Transition Probabilities between the Second Quarters of 2000 and 2001 (\%)

\begin{tabular}{|c|c|c|c|c|c|c|c|c|c|}
\hline & Peu & Pee & Peo & Puu & Pue & Puo & Pou & Poe & Poo \\
\hline All & 3.53 & 80.46 & 16.00 & 19.69 & 42.66 & 37.65 & 2.51 & 11.52 & 85.97 \\
\hline \multicolumn{10}{|l|}{ By Sex } \\
\hline Male & 4.05 & 86.77 & 9.18 & 19.57 & 53.62 & 26.81 & 5.13 & 20.06 & 74.8 \\
\hline Female & 2.01 & 68.98 & 29.01 & 24.12 & 20.59 & 55.29 & 1.66 & 7.68 & 90.66 \\
\hline \multicolumn{10}{|l|}{ By Place } \\
\hline Urban & 4.55 & 79.62 & 15.83 & 20.19 & 41.36 & 38.45 & 2.74 & 8.78 & 88.48 \\
\hline Rural & 1.42 & 82.22 & 16.36 & 15.63 & 53.13 & 31.25 & 1.52 & 23.34 & 75.15 \\
\hline \multicolumn{10}{|l|}{ By Urban-Male } \\
\hline Urban-Male & 4.75 & 85.64 & 9.61 & 19.69 & 52.00 & 28.31 & 5.35 & 17.79 & 76.86 \\
\hline Rural-Male & 2.20 & 89.76 & 8.04 & 18.75 & 64.58 & 16.67 & 4.13 & 30.23 & 65.63 \\
\hline Urban-Female & 3.76 & 65.38 & 30.86 & 25.16 & 20.75 & 54.09 & 1.88 & 4.82 & 93.30 \\
\hline Rural-Female & 0.11 & 72.88 & 27.01 & 9.09 & 18.18 & 72.73 & 0.73 & 19.87 & 79.40 \\
\hline \multicolumn{10}{|l|}{ Marital Status } \\
\hline Non-Married & 5.25 & 66.21 & 28.55 & 21.27 & 41.42 & 37.31 & 4.81 & 12.71 & 82.48 \\
\hline Married & 2.96 & 84.98 & 12.06 & 18.25 & 43.07 & 38.69 & 1.20 & 10.23 & 88.57 \\
\hline \multicolumn{10}{|l|}{ By Married-Male } \\
\hline Married-Male & 3.53 & 89.24 & 7.22 & 19.59 & 55.67 & 24.74 & 3.74 & 23.05 & 73.21 \\
\hline Non-Married-Male & 6.49 & 75.03 & 18.49 & 18.99 & 50.00 & 31.01 & 5.94 & 16.06 & 77.99 \\
\hline Married-Female & 0.91 & 71.35 & 27.74 & 16.00 & 13.33 & 70.67 & 0.71 & 7.47 & 91.81 \\
\hline Non-Married-Female & 4.03 & 64.26 & 31.71 & 31.40 & 25.58 & 43.02 & 4.34 & 8.20 & 87.46 \\
\hline \multicolumn{10}{|l|}{ Age Group } \\
\hline Age15-19 & 4.89 & 58.32 & 36.79 & 18.42 & 38.16 & 43.42 & 3.40 & 9.58 & 87.02 \\
\hline Age20-24 & 4.84 & 73.45 & 21.71 & 17.35 & 46.94 & 35.71 & 6.69 & 13.90 & 79.41 \\
\hline Age25-34 & 3.95 & 86.83 & 9.23 & 17.89 & 47.15 & 34.96 & 3.01 & 10.84 & 86.14 \\
\hline Age35-44 & 3.10 & 88.75 & 8.15 & 27.08 & 38.54 & 34.38 & 0.94 & 10.03 & 89.04 \\
\hline Age45-54 & 3.03 & 82.21 & 14.76 & 16.98 & 41.51 & 41.51 & 1.29 & 9.48 & 89.22 \\
\hline Age55pl & 1.42 & 73.30 & 25.28 & 5.26 & 36.84 & 57.89 & 0.36 & 9.47 & 90.17 \\
\hline \multicolumn{10}{|l|}{ By Age Group- MALE- } \\
\hline Age15-19 & 5.22 & 69.97 & 24.80 & 16.67 & 52.38 & 30.95 & 3.76 & 11.96 & 84.27 \\
\hline Age20-24 & 5.54 & 83.03 & 11.44 & 12.70 & 58.73 & 28.57 & 17.29 & 22.56 & 60.15 \\
\hline Age25-34 & 4.70 & 91.88 & 3.42 & 21.62 & 63.51 & 14.86 & 13.64 & 46.59 & 39.77 \\
\hline Age35-44 & 3.55 & 93.07 & 3.38 & 27.94 & 51.47 & 20.59 & 7.32 & 52.44 & 40.24 \\
\hline Age45-54 & 3.69 & 84.66 & 11.65 & 18.18 & 47.73 & 34.09 & 4.81 & 17.95 & 77.24 \\
\hline Age55pl & 1.92 & 76.76 & 21.32 & 5.88 & 35.29 & 58.82 & 0.97 & 14.20 & 84.82 \\
\hline \multicolumn{10}{|l|}{ By Age Group- FEMALE- } \\
\hline Age15-19 & 4.89 & 51.09 & 44.02 & 25.00 & 21.43 & 53.57 & 3.70 & 6.78 & 89.53 \\
\hline Age20-24 & 4.85 & 66.50 & 28.64 & 33.33 & 22.22 & 44.44 & 3.70 & 8.74 & 87.56 \\
\hline Age25-34 & 1.40 & 73.60 & 25.00 & 13.33 & 22.22 & 64.44 & 2.41 & 7.97 & 89.62 \\
\hline Age35-44 & 1.50 & 74.09 & 24.41 & 25.93 & 7.41 & 66.67 & 0.57 & 7.39 & 92.05 \\
\hline Age45-54 & 0.00 & 75.29 & 24.71 & 11.11 & 11.11 & 77.78 & 0.19 & 7.03 & 92.78 \\
\hline Age55pl & 0 & 63.29 & 36.71 & 0 & 50.00 & 50.00 & 0 & 6.60 & 93.40 \\
\hline \multicolumn{10}{|l|}{ Education Group } \\
\hline Non-Graduate & 3.04 & 68.69 & 28.27 & 7.69 & 38.46 & 53.85 & 0.45 & 12.00 & 87.55 \\
\hline Primary & 4.05 & 81.70 & 14.25 & 19.57 & 45.65 & 34.78 & 1.74 & 11.09 & 87.16 \\
\hline Middle School & 3.56 & 80.80 & 15.63 & 16.87 & 43.37 & 39.76 & 2.07 & 4.23 & 93.70 \\
\hline High School & 3.03 & 87.16 & 9.81 & 15.48 & 40.48 & 44.05 & 7.06 & 8.82 & 84.12 \\
\hline Voc. High School & 3.59 & 90.88 & 5.52 & 36.84 & 28.07 & 35.09 & 2.79 & 18.99 & 78.21 \\
\hline Two-Year University & 1.55 & 94.57 & 3.88 & 15.38 & 46.15 & 38.46 & 4.76 & 7.14 & 88.10 \\
\hline Four-Year Un.and over & 1.49 & 91.79 & 6.72 & 25.93 & 51.85 & 22.22 & 7.62 & 21.90 & 70.48 \\
\hline Number of Transitions & 298 & 6788 & 1350 & 114 & 247 & 218 & 246 & 1129 & 8423 \\
\hline Number of Observations & 8436 & 8436 & 8436 & 579 & 579 & 579 & 9798 & 9798 & 9798 \\
\hline
\end{tabular}


Table 6: Differences in Flow Probabilities $(\triangle P i)$ between Q1-2000 and Q1-2001

\begin{tabular}{|c|c|c|c|c|c|c|c|}
\hline & Peo & Peu & Pue & Puo & Pou & Poe & Pns \\
\hline Female-Male & 26.43 & -1.68 & -36.10 & 1.95 & -3.99 & -16.2 & 0.04 \\
\hline Rural-Urban & 10.17 & -1.31 & 1.28 & 5.07 & -0.86 & 13.28 & 0.15 \\
\hline Rural Male-Urban Male & 3.96 & -0.67 & 1.76 & 2.23 & -0.96 & 14.93 & 0.10 \\
\hline Rural Female-Urban Female & 12.65 & -1.84 & -15.87 & 5.27 & -1.08 & 11.98 & 0.23 \\
\hline UrbanFemale-UrbanMale & 21.90 & -1.05 & -34.10 & 1.82 & -3.98 & -15.26 & -0.03 \\
\hline Rural Female-Rural Male & 30.59 & -2.22 & -51.73 & 4.86 & -4.1 & -18.21 & 0.10 \\
\hline Non-Married-Married & 12.39 & 4.49 & -16.70 & 12.32 & 3.42 & 3.43 & -0.15 \\
\hline Non-Married Male-Married Male & 10.06 & 4.97 & -11.19 & 9.05 & 2.72 & -6.89 & -0.13 \\
\hline Non-Married Female - Married Female & -9.89 & 5.19 & -1.96 & 3.76 & 2.6 & 0.89 & -0.23 \\
\hline Married Female-Married Male & 30.43 & -2.45 & -37.70 & 2.19 & -3.3 & -19.13 & 0.06 \\
\hline Non Married Female-Non Married Male & 10.48 & -2.23 & -28.47 & -3.10 & -3.42 & -11.35 & -0.04 \\
\hline Female1519-Male1519 & 17.96 & 2.34 & -28.77 & -8.55 & -1.87 & -9.92 & -0.06 \\
\hline Female2024-Male2024 & 14.67 & -4.36 & -34.49 & 8.73 & -9.58 & -16.88 & 0.08 \\
\hline Female2534-Male2534 & 22.93 & -3.80 & -32.25 & 1.35 & -13.03 & -40.21 & 0.05 \\
\hline Female3544-Male3544 & 28.68 & -2.14 & -54.86 & -1.11 & -12.38 & -39.2 & 0.11 \\
\hline Female4554-Male4554 & 27.16 & -2.25 & -47.62 & -1.59 & -4.16 & -15.49 & 0.16 \\
\hline Female55pl-Male55pl & -23.97 & 51.06 & -50.00 & 0.00 & 4.56 & 81.91 & -0.02 \\
\hline Non-Graduate-Primary Edu. & 17.22 & -3.04 & -1.66 & 1.61 & -1.28 & -1.78 & 0.09 \\
\hline Non-Graduate-Middle School & 19.36 & -2.56 & -3.24 & 3.68 & -1.92 & 2.23 & 0.21 \\
\hline Non-Graduate-High School & 25.25 & -1.73 & 22.23 & -2.68 & -4.91 & -3.09 & 0.26 \\
\hline Non-Graduate-Voc.High School & 28.59 & -2.39 & 15.78 & -5.96 & -7.06 & -3.63 & 0.32 \\
\hline Non-Graduate-Two Year Univ. & 27.18 & -0.76 & -24.49 & -2.01 & -1.77 & -2.02 & 0.12 \\
\hline Non-Graduate-Four Year Univ. & 29.13 & 0.06 & -2.08 & -2.78 & -2.88 & -5.91 & 0.13 \\
\hline
\end{tabular}


Table 7: Differences in Flow Probabilities $(\Delta P i)$, Between Q2-2000 and Q2-2001

\begin{tabular}{|c|c|c|c|c|c|c|c|}
\hline & Peo & Peu & Pue & Puo & Pou & Poe & Pns \\
\hline Female-Male & 19.83 & -2.04 & -33.03 & 28.48 & -3.47 & -12.38 & 0.03 \\
\hline Rural-Urban & 0.53 & -3.13 & 11.77 & -7.20 & -1.22 & 14.56 & 0.18 \\
\hline Rural Male-Urban Male & -1.57 & -2.55 & 12.58 & -11.64 & -1.22 & 12.44 & 0.11 \\
\hline Rural Female-Urban Female & -3.85 & -3.65 & -2.57 & 18.64 & -1.15 & 15.05 & 0.25 \\
\hline UrbanFemale-UrbanMale & 21.25 & -0.99 & -31.25 & 25.78 & -3.47 & -12.97 & -0.05 \\
\hline Rural Female-Rural Male & 18.97 & -2.09 & -46.40 & 56.06 & -3.4 & -10.36 & 0.08 \\
\hline Non-Married-Married & 16.49 & 2.29 & -1.65 & -1.38 & 3.61 & 2.48 & -0.17 \\
\hline Non-Married Male-Married Male & 11.27 & 2.96 & -5.67 & 6.27 & 2.2 & -6.99 & -0.13 \\
\hline Non-Married Female - Married Female & 3.97 & 3.12 & 12.25 & -27.65 & 3.63 & 0.73 & -0.26 \\
\hline Married Female-Married Male & 20.52 & -2.62 & -42.34 & 45.93 & -3.03 & -15.58 & 0.05 \\
\hline Non Married Female-Non Married Male & 13.22 & -2.46 & -24.42 & 12.01 & -1.6 & -7.86 & -0.08 \\
\hline Female1519-Male1519 & 19.22 & -0.33 & -30.95 & 22.62 & -0.06 & -5.18 & -0.11 \\
\hline Female2024-Male2024 & 17.20 & -0.69 & -36.51 & 15.87 & -13.59 & -13.82 & 0.14 \\
\hline Female2534-Male2534 & 21.58 & -3.30 & -41.29 & 49.58 & -11.23 & -38.62 & -0.01 \\
\hline Female3544-Male3544 & 21.03 & -2.05 & -44.06 & 46.08 & -6.75 & -45.05 & 0.05 \\
\hline Female4554-Male4554 & 13.06 & -3.69 & -36.62 & 43.69 & -4.62 & -10.92 & 0.19 \\
\hline Female55pl-Male55pl & 15.39 & -1.92 & 14.71 & -8.82 & -0.97 & -7.6 & 0.06 \\
\hline Under Primary-Primary Edu. & 14.02 & -1.01 & -7.19 & 19.07 & -1.29 & 0.91 & 0.10 \\
\hline Under Primary-Middle School & 12.64 & -0.52 & -4.91 & 14.09 & -1.62 & 7.77 & 0.29 \\
\hline Under Primary-High School & 18.46 & 0.01 & -2.02 & 9.80 & -6.61 & 3.18 & 0.41 \\
\hline Under Primary-Voc.High School & 22.75 & -0.55 & 10.39 & 18.76 & -2.34 & -6.99 & 0.09 \\
\hline Under Primary-Two Years Univ. & 24.39 & 1.49 & -7.69 & 15.39 & -4.31 & 4.86 & 0.36 \\
\hline Under Primary-Four Years Univ. & 21.55 & 1.55 & -13.39 & 31.63 & -7.17 & -9.9 & 0.22 \\
\hline
\end{tabular}


Table 8: Partial Differences in Unemployment Rates Attributable to Transition Probabilities (Between Q1-2000 and Q1-2001)

\begin{tabular}{|c|c|c|c|c|c|c|}
\hline & $\mathrm{Peu}$ & Peo & Pue & Puo & Pns & Total Difference \\
\hline Female\&Male & 8.00 & -3.15 & 15.06 & -0.69 & -1.88 & 17.33 \\
\hline Rural\&Urban & -2.21 & 1.97 & 0.20 & 0.66 & 4.59 & 5.22 \\
\hline Rural Male\&Urban Male & 0.91 & -0.93 & -0.22 & -0.23 & -1.63 & -2.09 \\
\hline Rural Female\&Urban Female & 3.60 & -6.30 & 10.76 & -3.03 & -32.40 & -27.36 \\
\hline Urban Female\&Urban Male & 8.58 & -1.76 & 16.00 & -0.65 & 1.19 & 23.36 \\
\hline Rural Female\&Rural Male & 3.74 & -6.95 & 17.16 & -1.56 & -11.32 & 1.07 \\
\hline Non-Married\&Married & 2.99 & 6.50 & 4.08 & -2.36 & 4.77 & 15.98 \\
\hline Non-Married Male\&Married Male & 2.51 & 6.63 & 2.08 & -1.30 & 2.43 & 12.34 \\
\hline Non-Married Female\&Married Female & -3.51 & 12.64 & 1.35 & -2.00 & 20.72 & 29.21 \\
\hline Married Female\&Married Male & 6.26 & -5.76 & 9.62 & -0.51 & -4.19 & 5.42 \\
\hline Non-Married Female\&Non-Married Male & 4.18 & -3.16 & 17.62 & 1.36 & 1.53 & 21.53 \\
\hline Non-Graduate \&Primary Edu. & 2.37 & -4.67 & 0.21 & -0.18 & -3.65 & -5.93 \\
\hline Non-Graduate \&Middle School & 4.27 & -3.90 & 0.44 & -0.41 & -8.10 & -7.69 \\
\hline Non-Graduate \&High School & 9.48 & -3.31 & -4.97 & 0.44 & -10.20 & -8.56 \\
\hline Non-Graduate \&Voc. High School & 11.12 & -4.20 & -2.64 & 0.70 & -11.26 & -6.27 \\
\hline Non-Graduate\&Two Year Univ. & 3.64 & -1.05 & 1.51 & 0.11 & -3.82 & 0.39 \\
\hline Non-Graduate \&Four Year Univ. & 5.31 & 0.10 & 0.14 & 0.17 & -4.30 & 1.41 \\
\hline \multicolumn{7}{|l|}{ Prime Age (age25-54) and Education } \\
\hline Prim.\& Non-Graduate (Female\&Male) & 9.92 & -7.62 & 16.23 & -0.11 & -11.90 & 6.53 \\
\hline Mid.Sc.(Female\&Male) & 13.35 & -7.40 & 48.74 & 0.00 & 8.26 & 62.95 \\
\hline H.Sch.(Female\&Male) & 7.06 & 1.59 & 9.35 & -3.37 & 3.84 & 18.46 \\
\hline University (Female\&Male) & 1.78 & -0.14 & 1.47 & -0.42 & 0.58 & 3.26 \\
\hline
\end{tabular}

Table 9: Partial Differences in Unemployment Rates Attributable to Transition Probabilities (Between Q2-2000 and Q2-2001)

\begin{tabular}{|c|c|c|c|c|c|c|}
\hline & Peu & Peo & Pue & Puo & Pns & Total Difference \\
\hline Female-Male & 4.48 & -2.43 & 3.70 & -2.59 & -0.73 & 2.44 \\
\hline Rural-Urban & 0.09 & -3.56 & -0.98 & 0.48 & -3.78 & -7.76 \\
\hline Rural Male-Urban Male & -0.32 & -2.93 & -0.97 & 0.72 & -1.34 & -4.83 \\
\hline Rural Female-Urban Female & -0.70 & -4.11 & 0.32 & -1.72 & -9.71 & -15.91 \\
\hline Urban Female-Urban Male & 6.20 & -1.13 & 5.41 & -3.28 & 1.54 & 8.74 \\
\hline Rural Female-Rural Male & 1.70 & -2.37 & 1.39 & -1.51 & -1.74 & -2.53 \\
\hline NonMarried-Married & 3.33 & 2.50 & 0.21 & 0.14 & 4.50 & 10.69 \\
\hline NonMarried Male-Married Male & 2.47 & 3.23 & 0.65 & -0.56 & 2.22 & 8.03 \\
\hline NonMarried Female-Married Female & 0.99 & 3.62 & -2.25 & 3.51 & 11.16 & 17.02 \\
\hline Married Female-Married Male & 2.71 & -3.07 & 2.51 & -2.41 & -1.22 & -1.47 \\
\hline Non Married Female-Non Married Male & 4.43 & -2.66 & 5.86 & -1.96 & 2.81 & 8.48 \\
\hline Non-Graduate \&Primary Edu. & 1.34 & -1.08 & 0.49 & -1.16 & -2.51 & -2.93 \\
\hline Non-Graduate \&Middle School & 2.58 & -0.56 & 0.46 & -0.97 & -7.94 & -6.44 \\
\hline Non-Graduate \&High School & 5.43 & 0.01 & 0.19 & -0.60 & -10.11 & -5.08 \\
\hline Non-Graduate \&Voc.High School & 2.57 & -0.69 & -0.80 & -1.30 & -1.98 & -2.19 \\
\hline Non-Graduate\&Two Year Univ. & 6.90 & 1.74 & 0.40 & -0.61 & -7.01 & 1.43 \\
\hline Non-Graduate \&Four Year Univ. & 4.11 & 1.82 & 0.73 & -1.43 & -4.60 & 0.62 \\
\hline \multicolumn{7}{|l|}{ Prime Age (age25-54) and Education } \\
\hline Prim.\&Under (Female-Male) & 3.35 & -4.56 & 2.70 & -2.94 & -2.15 & -3.62 \\
\hline Mid.Sc.(Female-Male) & 10.32 & -3.71 & 8.15 & -4.19 & -6.22 & 4.35 \\
\hline H.Sch.(Female-Male) & 5.46 & -1.20 & 7.57 & -4.58 & 10.69 & 17.94 \\
\hline University (Female-Male) & 0.37 & 1.55 & 0.99 & -1.51 & -0.18 & 1.21 \\
\hline
\end{tabular}


Table 10: Transition from Employment to Unemployment and Out-of-the Labor Force

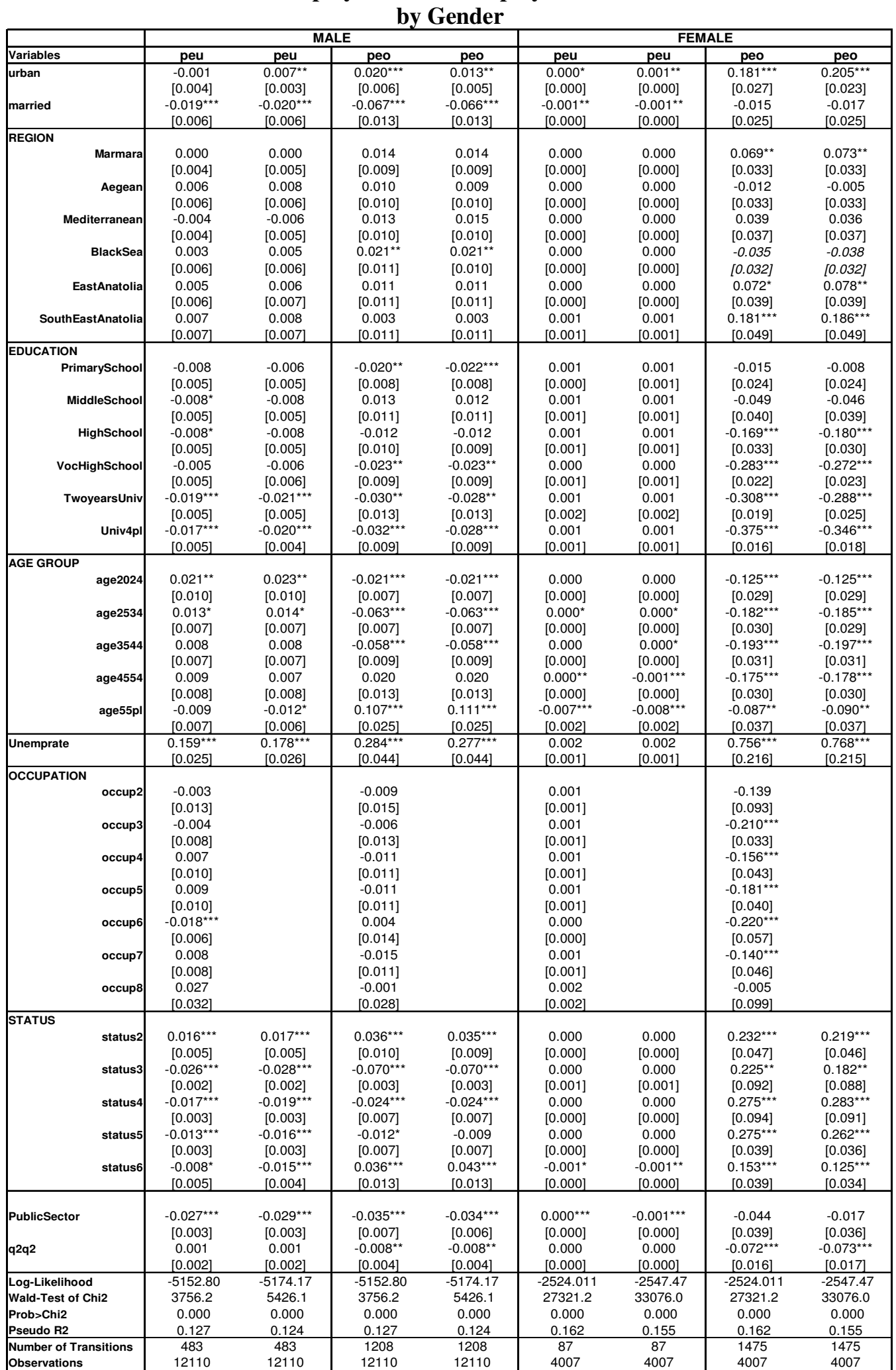

Note: 1) Standard errors in brackets.

2 ) $*$ significant at $10 \%$; ** significant at $5 \%$; *** significant at $1 \%$. 
Table 11: Transition from Unemployment to Employment and Out-of-Labor Force by Gender

\begin{tabular}{|c|c|c|c|c|c|c|c|c|}
\hline & & & & & & FEI & LLE & \\
\hline & pue & pue & Puo & Puo & pue & pue & Puo & Puo \\
\hline urban & $\begin{array}{c}0.041 \\
{[0.069]}\end{array}$ & $\begin{array}{l}-0.002 \\
{[0.057]}\end{array}$ & $\begin{array}{c}0.000 \\
{[0.011]}\end{array}$ & $\begin{array}{c}0.002 \\
{[0.010]}\end{array}$ & $\begin{array}{l}0.016^{*} \\
{[0.008]}\end{array}$ & $\begin{array}{l}0.059^{\star \star \star \star} \\
{[0.015]}\end{array}$ & $\begin{array}{c}-0.359^{* \star *} \\
{[0.119]}\end{array}$ & $\begin{array}{c}-0.373^{\star * \star} \\
{[0.105]}\end{array}$ \\
\hline married & 0.062 & $0.112^{*}$ & -0.010 & -0.019 & 0.000 & 0.015 & $0.165^{\star}$ & 0.136 \\
\hline & {$[0.075]$} & {$[0.066]$} & {$[0.011]$} & {$[0.012]$} & {$[0.010]$} & {$[0.027]$} & {$[0.097]$} & {$[0.091]$} \\
\hline REGION & & & & & & & & \\
\hline Marmara & 0.070 & 0.057 & -0.006 & -0.008 & 0.038 & 0.093 & 0.130 & 0.027 \\
\hline & {$[0.066]$} & {$[0.065]$} & {$[0.010]$} & {$[0.010]$} & {$[0.046]$} & [0.097] & {$[0.156]$} & [0.151] \\
\hline Aegean & 0.079 & 0.099 & -0.001 & -0.011 & 0.197 & 0.243 & -0.138 & -0.118 \\
\hline & {$[0.071]$} & {$[0.066]$} & {$[0.013]$} & {$[0.011]$} & {$[0.178]$} & {$[0.198]$} & {$[0.166]$} & {$[0.164]$} \\
\hline Mediterrian & $0.122^{*}$ & 0.095 & -0.003 & 0.001 & 0.157 & 0.179 & 0.129 & 0.064 \\
\hline BlackSea & $\begin{array}{c}{[0.065]} \\
0.100\end{array}$ & $\begin{array}{c}{[0.063]} \\
0.057\end{array}$ & $\begin{array}{l}{[0.011]} \\
-0.003\end{array}$ & $\begin{array}{c}{[0.013]} \\
0.003\end{array}$ & $\begin{array}{c}{[0.145]} \\
0.101\end{array}$ & $\begin{array}{l}{[0.147]} \\
0.087\end{array}$ & $\begin{array}{l}{[0.196]} \\
0.260\end{array}$ & $\begin{array}{l}{[0.170]} \\
0.188\end{array}$ \\
\hline & {$[0.077]$} & {$[0.073]$} & {$[0.013]$} & {$[0.016]$} & {$[0.122]$} & {$[0.131]$} & {$[0.173]$} & [0.179] \\
\hline EastAnatolia & -0.083 & -0.043 & 0.022 & 0.013 & $-0.037^{\star \star \star}$ & $-0.102^{\star \star \star *}$ & $0.451^{\star \star *}$ & $0.446^{\star \star * *}$ \\
\hline & {$[0.091]$} & {$[0.088]$} & {$[0.027]$} & {$[0.025]$} & [0.013] & [0.024] & {$[0.147]$} & {$[0.164]$} \\
\hline SouthEastAnatolia & $0.150^{\star \star}$ & $0.139^{* \star}$ & -0.008 & -0.007 & 0.087 & 0.029 & 0.254 & $0.303^{*}$ \\
\hline & {$[0.069]$} & {$[0.066]$} & {$[0.010]$} & {$[0.012]$} & {$[0.143]$} & {$[0.097]$} & {$[0.208]$} & {$[0.168]$} \\
\hline EDUCATION & & & & & & & & \\
\hline PrimarySchool & $\begin{array}{c}-0.019 \\
{[0.089]}\end{array}$ & $\begin{array}{c}0.015 \\
{[0.079]}\end{array}$ & $\begin{array}{l}-0.017 \\
{[0.012]}\end{array}$ & $\begin{array}{l}-0.025^{*} \\
{[0.014]}\end{array}$ & $\begin{array}{c}0.005 \\
{[0.017]}\end{array}$ & $\begin{array}{l}-0.001 \\
{[0.031]}\end{array}$ & $\begin{array}{l}-0.202^{\star} \\
{[0.111]}\end{array}$ & $\begin{array}{l}-0.220^{\star *} \\
{[0.098]}\end{array}$ \\
\hline MiddleSchool & 0.109 & $0.131^{\star}$ & $-0.014^{\star}$ & $-0.018^{\star \star}$ & -0.007 & -0.022 & $-0.279^{\star \star \star}$ & $-0.283^{\star \star \star *}$ \\
\hline & {$[0.093]$} & {$[0.078]$} & {$[0.008]$} & {$[0.009]$} & {$[0.014]$} & {$[0.027]$} & {$[0.097]$} & [0.088] \\
\hline HighSchool & 0.006 & -0.044 & -0.013 & -0.013 & 0.016 & -0.004 & $-0.227^{\star}$ & $-0.286^{\star \star \star}$ \\
\hline menconosi & {$[0.110]$} & {$[0.101]$} & {$[0.009]$} & {$[0.010]$} & {$[0.026]$} & [0.031] & {$[0.123]$} & [0.093] \\
\hline VocHighSchool & 0.110 & $0.155^{\star}$ & $-0.016^{\star \star}$ & $-0.021^{* * *}$ & 0.018 & 0.012 & $-0.477^{* * *}$ & $-0.479^{* \star *}$ \\
\hline & {$[0.102]$} & {$[0.083]$} & {$[0.008]$} & {$[0.007]$} & [0.039] & [0.041] & [0.051] & [0.049] \\
\hline TwoyearsUniv & $\begin{array}{l}0.234^{\star \star \star \star} \\
{[0.083]}\end{array}$ & $\begin{array}{l}0.202^{\star \star} \\
{[0.083]}\end{array}$ & $\begin{array}{l}-0.023^{* * \star} \\
{[0.006]}\end{array}$ & $\begin{array}{l}-0.022^{* \star \star *} \\
{[0.009]}\end{array}$ & $\begin{array}{l}0.650^{*} \\
{[0.377]}\end{array}$ & $\begin{array}{l}0.482^{*} \\
{[0.269]}\end{array}$ & $\begin{array}{l}-0.375^{\star \star \star *} \\
{[0.084]}\end{array}$ & $\begin{array}{l}-0.364^{* \star *} \\
{[0.107]}\end{array}$ \\
\hline Univ4pI & $0.344^{\star \star \star \star}$ & $0.253^{\star \star \star}$ & $-0.026^{\star * \star}$ & $-0.022^{* \star \star}$ & $0.765^{\star \star \star}$ & $0.333^{\star}$ & $-0.444^{\star \star \star}$ & $-0.432^{\star \star *}$ \\
\hline & {$[0.035]$} & {$[0.058]$} & {$[0.004]$} & {$[0.007]$} & {$[0.197]$} & {$[0.198]$} & {$[0.048]$} & {$[0.049]$} \\
\hline AGE GROUP & & & & & & & & \\
\hline age2024 & 0.087 & $0.112^{*}$ & $-0.014^{*}$ & $-0.022^{* \star \star}$ & 0.001 & 0.006 & -0.062 & -0.023 \\
\hline & {$[0.077]$} & {$[0.064]$} & {$[0.007]$} & [0.007] & [0.011] & [0.023] & [0.119] & [0.107] \\
\hline age2534 & -0.031 & 0.041 & $-0.021^{* *}$ & $-0.032^{\star \star \star}$ & -0.016 & -0.017 & -0.059 & 0.008 \\
\hline agerest & {$[0.095]$} & {$[0.079]$} & [0.009] & [0.008] & {$[0.010]$} & [0.024] & {$[0.127]$} & [0.116] \\
\hline age 3544 & $-0.182^{\star}$ & -0.089 & -0.014 & $-0.025^{\star \star \star \star}$ & $-0.031^{\star \star \star \star}$ & $-0.072^{\star \star \star \star}$ & $-0.215^{*}$ & -0.149 \\
\hline & {$[0.107]$} & [0.095] & [0.010] & [0.009] & [0.010] & [0.017] & [0.111] & [0.115] \\
\hline age4554 & $-0.265^{\star \star}$ & -0.155 & -0.005 & $-0.017^{*}$ & $-0.023^{\star * \star}$ & $-0.063^{\star \star \star}$ & -0.055 & 0.012 \\
\hline & {$[0.120]$} & [0.109] & [0.013] & {$[0.010]$} & {$[0.007]$} & [0.013] & {$[0.169]$} & [0.173] \\
\hline age55pl & $-0.299^{\star *}$ & -0.213 & 0.017 & 0.005 & NA & NA & NA & NA \\
\hline unemprate & $\frac{[0.131]}{-1.876^{\star \star \star}}$ & $\frac{[0.737]}{-1.950^{* \star \star *}}$ & $\frac{[0.025]}{0.062}$ & $\frac{[0.019]}{0.107}$ & $-0.385^{*}$ & -0.519 & -0.756 & -1.020 \\
\hline & {$[0.686]$} & {$[0.662]$} & {$[0.118]$} & {$[0.126]$} & [0.224] & {$[0.483]$} & [1.777] & [1.503] \\
\hline OCCUPATION & & & & & & & & \\
\hline occup2 & $\begin{array}{c}0.215 \\
{[0.155]}\end{array}$ & & $\begin{array}{c}-0.023^{\star \star \star *} \\
{[0.005]}\end{array}$ & & NA & & NA & \\
\hline occup3 & $0.326^{* \star \star *}$ & & $-0.026^{\star \star \star}$ & & $0.300^{* \star}$ & & $-0.306^{* \star *}$ & \\
\hline & [0.040] & & [0.004] & & {$[0.135]$} & & [0.094] & \\
\hline occup4 & $\begin{array}{l}0.350^{\star \star *} \\
{[0.046]}\end{array}$ & & $\begin{array}{c}-0.032^{\star \star \star} \\
{[0.006]}\end{array}$ & & $\begin{array}{c}0.061 \\
{[0.058]}\end{array}$ & & $\begin{array}{c}-0.428^{\star \star \star} \\
{[0.051]}\end{array}$ & \\
\hline occup5 & $0.370^{\star \star \star}$ & & $-0.031^{\star \star \star *}$ & & $0.782^{* \star *}$ & & $-0.396^{\star \star *}$ & \\
\hline & [0.042] & & [0.005] & & {$[0.168]$} & & [0.056] & \\
\hline occup6 & $0.398^{\star \star \star}$ & & $-0.032^{\star \star \star}$ & & 0.258 & & $-0.227^{\star}$ & \\
\hline & [0.038] & & {$[0.006]$} & & {$[0.163]$} & & [0.118] & \\
\hline occup 7 & $\begin{array}{l}0.577^{\star \star \star} \\
{[0.072]}\end{array}$ & & $\begin{array}{l}-0.076^{\star \star \star \star} \\
{[0.017]}\end{array}$ & & $\begin{array}{l}0.650^{* \star \star \star} \\
{[0.147]}\end{array}$ & & $\begin{array}{l}-0.297^{\star \star \star \star} \\
{[0.073]}\end{array}$ & \\
\hline occup8 & $0.299^{\star \star \star}$ & & $-0.022^{\star \star \star \star}$ & & 0.385 & & $-0.331^{\star \star \star}$ & \\
\hline & {$[0.059]$} & & {$[0.006]$} & & {$[0.524]$} & & {$[0.105]$} & \\
\hline STATUS & & & & & & & & \\
\hline status2 & -0.060 & 0.027 & 0.011 & -0.006 & -0.009 & 0.063 & -0.153 & $-0.252^{\star * *}$ \\
\hline & [0.054] & [0.045] & [0.009] & {$[0.007]$} & [0.010] & [0.068] & [0.158] & {$[0.097]$} \\
\hline status3 & NA & NA & NA & NA & $\begin{array}{c}-0.018^{* \star \star} \\
{[0.006]}\end{array}$ & $\begin{array}{c}0.049 \\
{[0.071]}\end{array}$ & $\begin{array}{c}0.331 \\
{[0.213]}\end{array}$ & $\begin{array}{c}0.037 \\
{[0.219]}\end{array}$ \\
\hline status 4 & $0.309^{\star * *}$ & $0.292^{* * *}$ & -0.014 & -0.018 & NA & NA & NA & NA \\
\hline status5 & $\begin{array}{l}{[0.045]} \\
0.247^{\star \star \star}\end{array}$ & $\begin{array}{l}{[0.046]} \\
0.262^{\star \star \star}\end{array}$ & $\begin{array}{c}{[0.012]} \\
-0.019^{\star \star \star}\end{array}$ & $\begin{array}{c}{[0.014]} \\
-0.028^{\star \star \star}\end{array}$ & 0.057 & $0.669^{\star \star}$ & -0.267 & $-0.374^{\star \star \star *}$ \\
\hline & {$[0.050]$} & [0.040] & [0.006] & [0.006] & {$[0.073]$} & {$[0.276]$} & {$[0.208]$} & [0.132] \\
\hline status6 & $0.218^{\star \star \star}$ & $0.305^{\star \star \star \star}$ & $-0.103^{\star \star \star}$ & $-0.113^{\star \star \star}$ & NA & NA & NA & NA \\
\hline & {$[0.079]$} & {$[0.048]$} & {$[0.015]$} & {$[0.014]$} & & & & \\
\hline DURATION & & & & & & & & \\
\hline duration 46 & -0.084 & -0.082 & 0.002 & 0.003 & $-0.022^{\star * *}$ & $-0.068^{\star \star \star}$ & 0.063 & 0.150 \\
\hline & [0.056] & [0.052] & [0.009] & {$[0.010]$} & {$[0.010]$} & [0.018] & [0.110] & [0.103] \\
\hline duration612 & -0.096 & $-0.102^{*}$ & 0.017 & $0.024^{*}$ & -0.010 & $-0.031^{*}$ & -0.145 & -0.093 \\
\hline & [0.062] & [0.057] & [0.012] & [0.013] & [0.008] & {$[0.018]$} & {$[0.101]$} & {$[0.101]$} \\
\hline duration 1224 & -0.054 & -0.056 & $0.061^{*}$ & $0.077^{\star \star *}$ & $-0.020^{\star \star \star \star}$ & $-0.047^{\star \star \star \star}$ & -0.013 & 0.093 \\
\hline & {$[0.102]$} & [0.093] & [0.031] & [0.037] & {$[0.008]$} & [0.016] & {$[0.144]$} & [0.134] \\
\hline duration24pI & -0.109 & -0.115 & $0.139^{\star \star}$ & $0.150^{* \star}$ & -0.004 & $-0.050^{* \star *}$ & -0.044 & 0.062 \\
\hline & {$[0.136]$} & {$[0.127]$} & {$[0.060]$} & {$[0.069]$} & {$[0.021]$} & {$[0.017]$} & {$[0.186]$} & {$[0.187]$} \\
\hline SEARCH METHOD & & & & & & & & \\
\hline Friendsetc & 0.064 & $\begin{array}{c}0.055 \\
{[0.043]}\end{array}$ & $\begin{array}{l}-0.010 \\
{[0.008]}\end{array}$ & $\begin{array}{l}-0.009 \\
{[0.008]}\end{array}$ & $\begin{array}{c}0.005 \\
{[0.010]}\end{array}$ & $\begin{array}{l}-0.024 \\
{[0.025]}\end{array}$ & $\begin{array}{l}-0.020 \\
{[0.100]}\end{array}$ & $\begin{array}{c}0.002 \\
{[0.091]}\end{array}$ \\
\hline Newspapers & $0.125^{\star \star}$ & $0.114^{\star \star}$ & 0.002 & 0.006 & 0.012 & $\begin{array}{l}-0.004 \\
-0.04\end{array}$ & 0.161 & 0.159 \\
\hline & {$[0.057]$} & {$[0.054]$} & {$[0.013]$} & {$[0.014]$} & {$[0.026]$} & {$[0.036]$} & {$[0.195]$} & {$[0.141]$} \\
\hline Employmentoffice & 0.036 & -0.002 & $-0.022^{\star \star \star \star}$ & $-0.024^{\star \star \star \star}$ & -0.005 & $-0.039^{\star \star}$ & -0.001 & -0.028 \\
\hline & {$[0.074]$} & {$[0.071]$} & {$[0.006]$} & {$[0.006]$} & {$[0.012]$} & {$[0.016]$} & {$[0.148]$} & {$[0.125]$} \\
\hline Workersagent & $0.263^{* \star \star \star}$ & $0.221^{\star \star \star}$ & $-0.020^{\star \star \star *}$ & $-0.020^{*}$ & 0.001 & -0.015 & -0.037 & -0.074 \\
\hline & {$[0.089]$} & {$[0.085]$} & {$[0.007]$} & {$[0.010]$} & [0.029] & {$[0.037]$} & [0.234] & {$[0.209]$} \\
\hline Trytoprovideequipment & $\begin{array}{l}-0.333^{\star \star} \\
{[0.140]}\end{array}$ & $\begin{array}{l}-0.324^{\star \star} \\
{[0.147]}\end{array}$ & $\begin{array}{c}0.022 \\
{[0.032]}\end{array}$ & $\begin{array}{c}0.013 \\
{[0.027]}\end{array}$ & $\begin{array}{l}-0.023^{* \star \star} \\
{[0.007]}\end{array}$ & $\begin{array}{l}-0.065^{\star \star \star \star} \\
{[0.015]}\end{array}$ & $\begin{array}{c}0.067 \\
{[0.248]}\end{array}$ & $\begin{array}{c}0.013 \\
{[0.246]}\end{array}$ \\
\hline Othermethods & -0.259 & $-0.320^{\star \star}$ & $-0.020^{\star \star \star \star}$ & $-0.022^{\star \star}$ & $-0.027^{\star \star \star \star}$ & $-0.077^{\star \star \star \star}$ & 0.201 & 0.294 \\
\hline & {$[0.168]$} & {$[0.153]$} & {$[0.006]$} & {$[0.010]$} & {$[0.009]$} & {$[0.017]$} & {$[0.273]$} & {$[0.219]$} \\
\hline $\mathbf{q 2 q 2}$ & 0.035 & 0.051 & $0.066^{* \star \star}$ & $0.067^{\star \star \star}$ & -0.009 & -0.011 & $0.657^{\star \star \star \star}$ & $0.588^{\star \star \star *}$ \\
\hline & {$[0.042]$} & {$[0.039]$} & {$[0.011]$} & {$[0.010]$} & {$[0.007]$} & {$[0.015]$} & {$[0.050]$} & {$[0.052]$} \\
\hline Log-Likelihood & -666.234 & -718.65 & -666.234 & -718.65 & -220.91 & -277.19 & -220.91 & -277.19 \\
\hline Wald-Test of Chi2 & 12103.99 & 10062.75 & 12103.99 & 10062.75 & 10716.70 & 12666.56 & 10716.70 & 12666.56 \\
\hline Prob>Chi2 & 0.0000 & 0.0000 & 0.0000 & 0.0000 & 0.0000 & 0.0000 & 0.0000 & 0.0000 \\
\hline Pseudo R2 & 0.2457 & 0.1864 & 0.2457 & 0.1864 & 0.4573 & 0.3190 & 0.4573 & 0.3190 \\
\hline Number of transitions & 493 & 493 & 149 & 149 & 77 & 77 & 154 & 154 \\
\hline Observations & 897 & 897 & 897 & 897 & 386 & 386 & 386 & 386 \\
\hline
\end{tabular}

Notes:1) See Table 10.

2) NA:Not Applicable 
Table 12: Transition from Out-of-the Labor Force to Employment and Unemployment by Gender



Note: See Table 11. 
Figure 1: Trends in Unemployment Rates by Gender and Residence, Turkey $1988 / 2004$

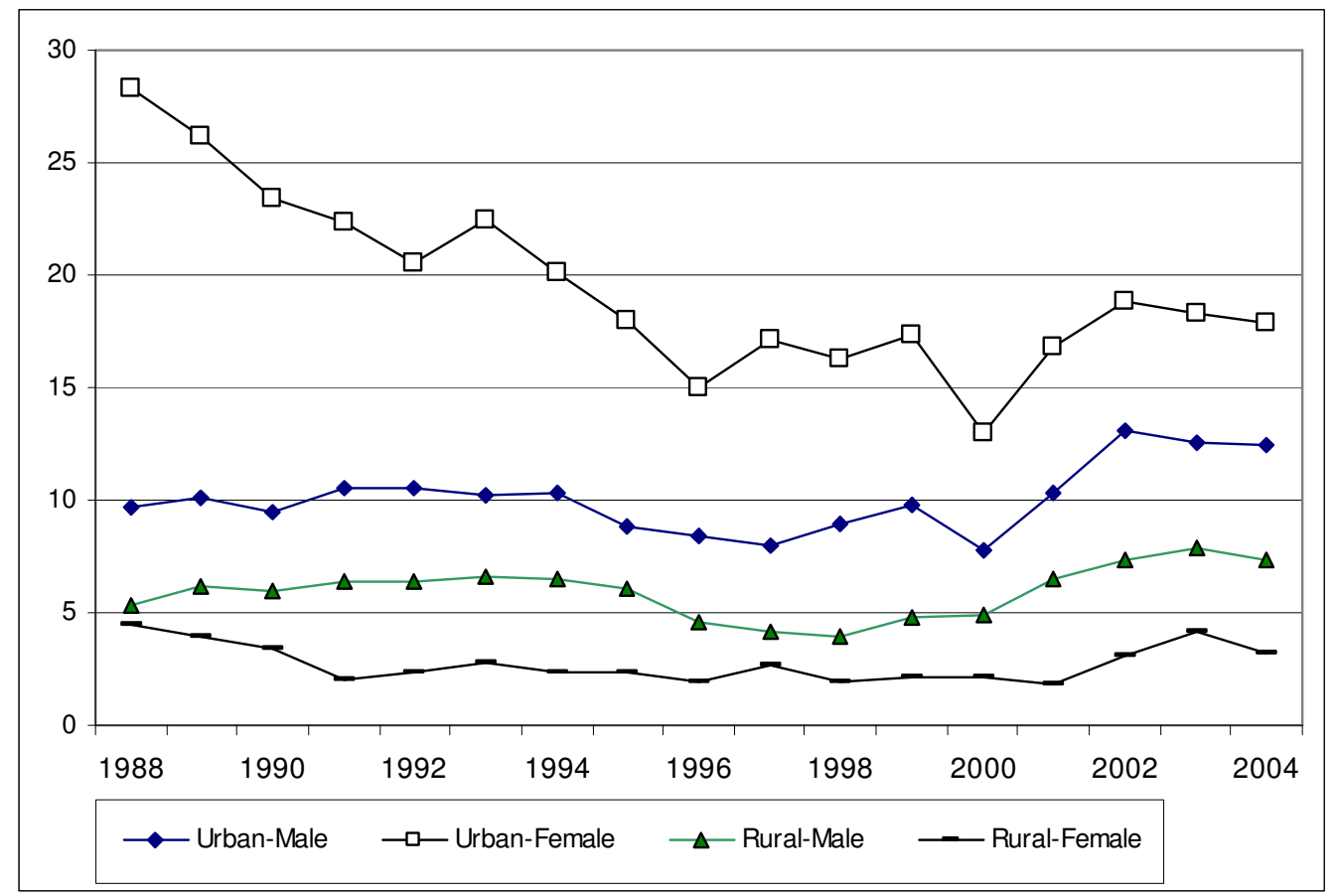

Source: SIS Database, 2004, SIS (2005).

Figure 2: Trends in Unemployment Rates by Gender and Marriage, Turkey $1988 / 2003$

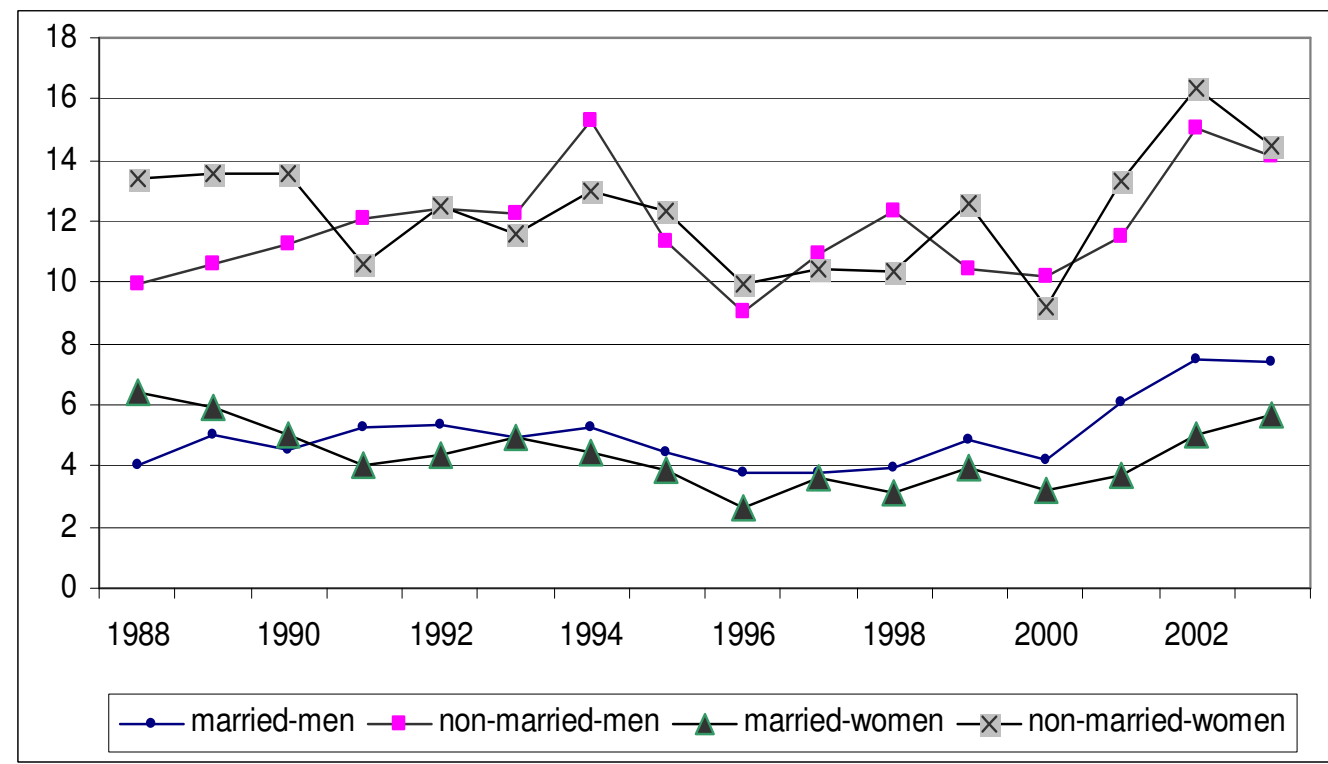

Source: SIS Database, 2004

${ }^{5}$ The unemployment rate data by marriage for 2004 were not available when this article written. 
APPENDIX

Table 1: Summary Statistics of the Variables for Each Transition Model by Gender

\begin{tabular}{|c|c|c|c|c|c|c|c|c|c|c|c|c|}
\hline & \multicolumn{4}{|c|}{ Employment } & \multicolumn{4}{|c|}{ Unemployment } & \multicolumn{4}{|c|}{ Out of Labor Force } \\
\hline & \multicolumn{2}{|c|}{ Men } & \multicolumn{2}{|c|}{ Women } & \multicolumn{2}{|c|}{ Men } & \multicolumn{2}{|c|}{ Women } & \multicolumn{2}{|c|}{ Men } & \multicolumn{2}{|c|}{ Women } \\
\hline & Mean & Std. Dev & Mean & Std. Dev & Mean & Std. Dev & Mean & Std. Dev & Mean & Std. Dev & Mean & Std. Dev \\
\hline urban & 0.735 & 0.441 & 0.557 & 0.497 & 0.834 & 0.372 & 0.896 & 0.305 & 0.790 & 0.407 & 0.802 & 0.399 \\
\hline married & 0.832 & 0.374 & 0.636 & 0.481 & 0.595 & 0.491 & 0.389 & 0.488 & 0.463 & 0.499 & 0.728 & 0.445 \\
\hline Marmara & 0.242 & 0.428 & 0.219 & 0.414 & 0.242 & 0.428 & 0.298 & 0.458 & 0.221 & 0.415 & 0.235 & 0.424 \\
\hline Aegean & 0.133 & 0.339 & 0.160 & 0.366 & 0.147 & 0.354 & 0.168 & 0.375 & 0.126 & 0.332 & 0.140 & 0.347 \\
\hline CentralAnatolia & 0.152 & 0.359 & 0.114 & 0.318 & 0.204 & 0.403 & 0.210 & 0.408 & 0.179 & 0.383 & 0.171 & 0.377 \\
\hline Mediterrianean & 0.141 & 0.348 & 0.207 & 0.405 & 0.111 & 0.315 & 0.166 & 0.372 & 0.181 & 0.385 & 0.168 & 0.373 \\
\hline BlackSea & 0.144 & 0.352 & 0.140 & 0.347 & 0.126 & 0.332 & 0.085 & 0.280 & 0.129 & 0.335 & 0.116 & 0.320 \\
\hline EastAnatolia & 0.109 & 0.312 & 0.105 & 0.306 & 0.079 & 0.270 & 0.021 & 0.143 & 0.108 & 0.311 & 0.116 & 0.320 \\
\hline SouthEastAnatolia & 0.079 & 0.270 & 0.055 & 0.229 & 0.090 & 0.287 & 0.052 & 0.222 & 0.073 & 0.260 & 0.080 & 0.272 \\
\hline Non-Graduate & 0.056 & 0.230 & 0.205 & 0.404 & 0.060 & 0.238 & 0.091 & 0.288 & 0.087 & 0.282 & 0.229 & 0.420 \\
\hline PrimarySchool & 0.526 & 0.499 & 0.431 & 0.495 & 0.547 & 0.498 & 0.365 & 0.482 & 0.352 & 0.478 & 0.516 & 0.500 \\
\hline MiddleSchool & 0.134 & 0.341 & 0.067 & 0.250 & 0.132 & 0.338 & 0.140 & 0.347 & 0.283 & 0.451 & 0.108 & 0.311 \\
\hline HighSchool & 0.122 & 0.327 & 0.107 & 0.309 & 0.136 & 0.343 & 0.228 & 0.420 & 0.164 & 0.370 & 0.094 & 0.292 \\
\hline VocHighSchool & 0.069 & 0.253 & 0.062 & 0.241 & 0.064 & 0.244 & 0.091 & 0.288 & 0.064 & 0.246 & 0.031 & 0.173 \\
\hline Twoyear Univ. & 0.022 & 0.146 & 0.029 & 0.167 & 0.029 & 0.168 & 0.023 & 0.151 & 0.019 & 0.135 & 0.008 & 0.087 \\
\hline Fouryear Univ. Plus & 0.072 & 0.258 & 0.099 & 0.299 & 0.032 & 0.177 & 0.047 & 0.211 & 0.032 & 0.175 & 0.014 & 0.117 \\
\hline age1519 & 0.068 & 0.251 & 0.124 & 0.330 & 0.137 & 0.344 & 0.187 & 0.390 & 0.364 & 0.481 & 0.146 & 0.354 \\
\hline age2024 & 0.062 & 0.242 & 0.148 & 0.355 & 0.202 & 0.402 & 0.275 & 0.447 & 0.122 & 0.327 & 0.107 & 0.309 \\
\hline age2534 & 0.262 & 0.440 & 0.242 & 0.428 & 0.253 & 0.435 & 0.306 & 0.461 & 0.079 & 0.270 & 0.225 & 0.418 \\
\hline age3544 & 0.327 & 0.469 & 0.256 & 0.437 & 0.217 & 0.413 & 0.166 & 0.372 & 0.058 & 0.233 & 0.223 & 0.416 \\
\hline age4554 & 0.192 & 0.394 & 0.144 & 0.351 & 0.142 & 0.349 & 0.054 & 0.227 & 0.154 & 0.361 & 0.173 & 0.378 \\
\hline age55pl & 0.088 & 0.284 & 0.086 & 0.280 & 0.049 & 0.216 & 0.013 & 0.113 & 0.223 & 0.417 & 0.126 & 0.331 \\
\hline Unemprate & 0.106 & 0.052 & 0.099 & 0.048 & 0.093 & 0.033 & 0.093 & 0.029 & 0.079 & 0.036 & 0.077 & 0.035 \\
\hline occup1 & 0.084 & 0.277 & 0.133 & 0.339 & 0.028 & 0.165 & 0.057 & 0.232 & 0.047 & 0.212 & 0.018 & 0.132 \\
\hline occup2 & 0.032 & 0.175 & 0.011 & 0.107 & 0.013 & 0.115 & 0.000 & 0.000 & 0.015 & 0.121 & 0.002 & 0.040 \\
\hline occup3 & 0.065 & 0.246 & 0.115 & 0.319 & 0.025 & 0.155 & 0.119 & 0.324 & 0.045 & 0.206 & 0.024 & 0.153 \\
\hline occup4 & 0.162 & 0.369 & 0.062 & 0.241 & 0.110 & 0.314 & 0.070 & 0.255 & 0.072 & 0.259 & 0.012 & 0.107 \\
\hline occup5 & 0.128 & 0.335 & 0.078 & 0.269 & 0.117 & 0.322 & 0.067 & 0.251 & 0.091 & 0.288 & 0.015 & 0.121 \\
\hline occup6 & 0.160 & 0.367 & 0.436 & 0.496 & 0.098 & 0.298 & 0.060 & 0.237 & 0.105 & 0.307 & 0.109 & 0.312 \\
\hline occup7 & 0.362 & 0.481 & 0.156 & 0.363 & 0.494 & 0.500 & 0.135 & 0.342 & 0.244 & 0.430 & 0.040 & 0.196 \\
\hline occup8 & 0.006 & 0.080 & 0.008 & 0.092 & 0.009 & 0.094 & 0.008 & 0.088 & 0.009 & 0.094 & 0.003 & 0.056 \\
\hline status1 & 0.469 & 0.499 & 0.401 & 0.490 & 0.369 & 0.483 & 0.383 & 0.487 & 0.345 & 0.476 & 0.084 & 0.277 \\
\hline status2 & 0.118 & 0.323 & 0.068 & 0.252 & 0.324 & 0.468 & 0.070 & 0.255 & 0.090 & 0.287 & 0.021 & 0.144 \\
\hline status3 & 0.001 & 0.024 & 0.010 & 0.099 & 0.000 & 0.000 & 0.018 & 0.134 & 0.000 & 0.014 & 0.002 & 0.045 \\
\hline status4 & 0.082 & 0.274 & 0.013 & 0.112 & 0.025 & 0.155 & 0.000 & 0.000 & 0.019 & 0.137 & 0.001 & 0.027 \\
\hline status5 & 0.270 & 0.444 & 0.141 & 0.348 & 0.134 & 0.341 & 0.021 & 0.143 & 0.114 & 0.318 & 0.031 & 0.174 \\
\hline status6 & 0.060 & 0.237 & 0.368 & 0.482 & 0.042 & 0.202 & 0.000 & 0.000 & 0.060 & 0.237 & 0.084 & 0.277 \\
\hline PublicSector & 0.205 & 0.404 & 0.168 & 0.374 & & & & & & & & \\
\hline duration13 & & & & & 0.541 & 0.499 & 0.360 & 0.481 & & & & \\
\hline duration46 & & & & & 0.205 & 0.404 & 0.233 & 0.423 & & & & \\
\hline duration612 & & & & & 0.163 & 0.369 & 0.236 & 0.425 & & & & \\
\hline duration1224 & & & & & 0.055 & 0.227 & 0.124 & 0.330 & & & & \\
\hline duration24pl & & & & & 0.037 & 0.188 & 0.047 & 0.211 & & & & \\
\hline Personally & & & & & 0.926 & 0.261 & 0.785 & 0.411 & & & & \\
\hline Friendsetc & & & & & 0.715 & 0.452 & 0.775 & 0.418 & & & & \\
\hline Newspapers & & & & & 0.082 & 0.275 & 0.067 & 0.251 & & & & \\
\hline Employment Office & & & & & 0.078 & 0.268 & 0.098 & 0.298 & & & & \\
\hline Workersagent & & & & & 0.025 & 0.155 & 0.010 & 0.101 & & & & \\
\hline Try to provide own Eq. & & & & & 0.020 & 0.140 & 0.005 & 0.072 & & & & \\
\hline Othermethods & & & & & 0.013 & 0.115 & 0.010 & 0.101 & & & & \\
\hline q2q2 & 0.514 & 0.500 & 0.552 & 0.497 & 0.478 & 0.500 & 0.562 & 0.497 & 0.614 & 0.487 & 0.661 & 0.473 \\
\hline Number of Obs. & 12110 & & 4007 & & 897 & & 386 & & 5227 & & 15357 & \\
\hline
\end{tabular}

